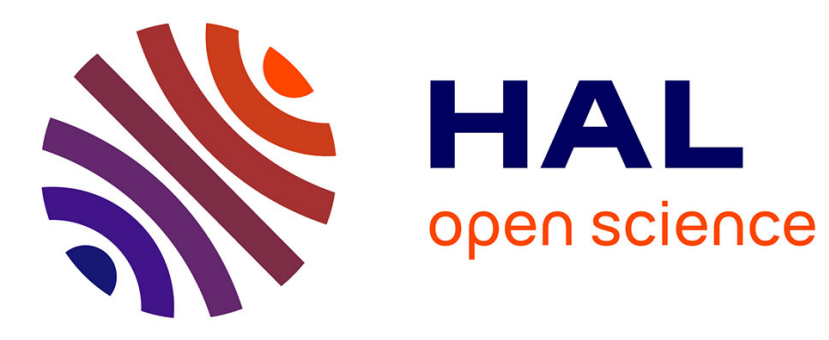

\title{
CRHR1-dependent effects on protein expression and posttranslational modification in AtT-20 cells
}

Helena C. Kronsbein, Archana M. Jastorff, Giuseppina Maccarrone, Günter Stalla, Wolfgang Wurst, Florian Holsboer, Christoph W. Turck, Jan M. Deussing

\section{To cite this version:}

Helena C. Kronsbein, Archana M. Jastorff, Giuseppina Maccarrone, Günter Stalla, Wolfgang Wurst, et al.. CRHR1-dependent effects on protein expression and posttranslational modification in AtT20 cells. Molecular and Cellular Endocrinology, 2008, 292 (1-2), pp.1. 10.1016/j.mce.2008.05.017 . hal-00532030

\section{HAL Id: hal-00532030 https://hal.science/hal-00532030}

Submitted on 4 Nov 2010

HAL is a multi-disciplinary open access archive for the deposit and dissemination of scientific research documents, whether they are published or not. The documents may come from teaching and research institutions in France or abroad, or from public or private research centers.
L'archive ouverte pluridisciplinaire HAL, est destinée au dépôt et à la diffusion de documents scientifiques de niveau recherche, publiés ou non, émanant des établissements d'enseignement et de recherche français ou étrangers, des laboratoires publics ou privés. 


\section{Accepted Manuscript}

Title: CRHR1-dependent effects on protein expression and posttranslational modification in AtT-20 cells

Authors: Helena C. Kronsbein, Archana M. Jastorff, Giuseppina Maccarrone, Günter Stalla, Wolfgang Wurst, Florian Holsboer, Christoph W. Turck, Jan M. Deussing

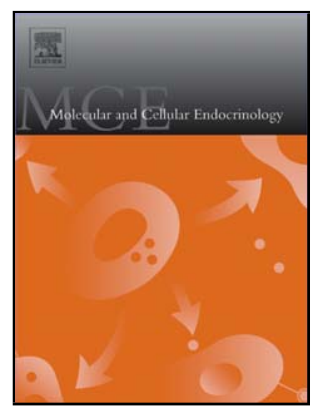

PII: S0303-7207(08)00246-3

DOI: doi:10.1016/j.mce.2008.05.017

Reference: MCE 6890

To appear in: Molecular and Cellular Endocrinology

Received date: 28-2-2008

Revised date: 26-5-2008

Accepted date: $27-5-2008$

Please cite this article as: Kronsbein, H.C., Jastorff, A.M., Maccarrone, G., Stalla, G., Wurst, W., Holsboer, F., Turck, C.W., Deussing, J.M., CRHR1-dependent effects on protein expression and posttranslational modification in AtT-20 cells, Molecular and Cellular Endocrinology (2007), doi:10.1016/j.mce.2008.05.017

This is a PDF file of an unedited manuscript that has been accepted for publication. As a service to our customers we are providing this early version of the manuscript. The manuscript will undergo copyediting, typesetting, and review of the resulting proof before it is published in its final form. Please note that during the production process errors may be discovered which could affect the content, and all legal disclaimers that apply to the journal pertain. 


\section{CRHR1-dependent effects on protein expression and posttranslational modification in AtT-20 cells}

Helena C. Kronsbein ${ }^{\star}$, Archana M. Jastorff*, Giuseppina Maccarrone*, Günter Stalla*, Wolfgang Wurst $^{\#}$, Florian Holsboer $*$, Christoph W. Turck ${ }^{*}$, Jan M. Deussing ${ }^{\star 1}$

$\$ \quad$ Max Planck Institute of Psychiatry

Kraepelinstraße 2-10

D-80804 Munich, Germany

\# Helmholtz Center Munich, German Research Center for Environmental Health Institute of Developmental Genetics Ingolstädter Landstraße 1

D-85764 Munich-Neuherberg, Germany

${ }^{1}$ Correspondence should be addressed to

Jan M. Deussing (deussing@mpipsykl.mpg.de)

or to Christoph W. Turck (turck@mpipsykl.mpg.de).

Phone: +49-(0)89-30622-369

Fax: +49-(0)89-30622-610 
Keywords: hypothalamic-pituitary-adrenocortical axis

corticotropin-releasing hormone

corticotropin-releasing hormone receptor type 1

AtT-20 cells

proteome analysis 


\begin{abstract}
Corticotropin-releasing hormone $(\mathrm{CRH})$ plays a major role in coordinating the organism's stress response, including the activity of the hypothalamic-pituitary-adrenocortical axis. The molecular underpinnings of CRH-dependent signal transduction mechanisms in the anterior pituitary have not yet been revealed in detail. In order to dissect the signal transduction cascades activated by $\mathrm{CRH}$ receptor type 1, a comparative proteome approach was performed in vitro utilizing murine corticotroph AtT-20 cells. Alterations in protein expression and posttranslational modification in response to $\mathrm{CRH}$ stimulation were studied by 2D gel electrophoresis. Selected candidates were analyzed by immunoblotting and quantitative real-time PCR. The differential analyses revealed proteins regulated or modified related to diverse cellular processes. Amongst others we identified alterations in PRKAR1A, the regulatory subunit of protein kinase A; in PGK1 and PGAM1, key regulators of glycolysis; and in proteins involved in proteasome-mediated proteolysis, PSMC2 and PSMA3. These results offer novel entry points to molecular mechanisms underlying stress responses elicited via the hypothalamic-pituitary-adrenocortical axis.
\end{abstract}




\section{Introduction}

Biologically active corticotropin-releasing hormone (CRH) is a 41-amino acid neuropeptide that plays a central role in integrating the neuroendocrine, autonomic, immune, and behavioral responses to stress (Smith and Vale, 2006). In response to physical or psychological stressors, $\mathrm{CRH}$ is released from the paraventricular hypothalamic nucleus into the portal vasculature of the pituitary. In the anterior pituitary $\mathrm{CRH}$ stimulates the expression of the hormone precursor molecule proopiomelanocortin (POMC) and the release of adrenocorticotropic hormone (ACTH) into the circulation. In turn, the synthesis and secretion of corticosteroids from the adrenal cortex, in particular glucocorticoids like cortisol in humans and corticosterone in rodents is stimulated by ACTH. The homeostatic balance of this hypothalamic-pituitary-adrenocortical (HPA) axis varies between individuals and is determined by genetic and environmental factors as well as early life experience (Coplan et al., 1996). Clinical and preclinical research has demonstrated a crucial function of the CRH system in the etiology and pathophysiology of stress-related and affective diseases, including anxiety disorders and major depression (de Kloet et al., 2005; Holsboer, 1999; Nemeroff et al., 1984). In patients suffering from major depression dysfunction of the HPA axis is one of the most robust findings (Holsboer, 2000). Chronic hypersecretion of central CRH enhances the activity of CRH-dependent circuitries within the limbic system, which play a pivotal role in mediating behavioral responses to stress (Deussing and Wurst, 2005; Keck and Holsboer, 2001).

$\mathrm{CRH}$ receptors belong to the class $\mathrm{B}$ subtype of $\mathrm{G}$ protein-coupled seven transmembrane receptors. CRH receptor type 1 (CRHR1) is widely distributed throughout the brain including the cerebral cortex, hippocampus, amygdala, cerebellum, olfactory bulb and pituitary (Van Pett et al., 
2000; Potter et al., 1994). CRH receptor type 2 (CRHR2) expression is limited within the central nervous system but is more prominent in peripheral tissues (Lovenberg et al., 1995). In most, but not all tissues, stimulation of both, CRHR1 and CRHR2 triggers the activation of $\mathrm{G}_{\mathrm{S}}$-dependent adenylate cyclase signaling pathways (Grammatopoulos et al., 1994). However, depending on the origin of investigated cell lines or tissues, coupling to alternative G-proteins and signaling cascades has been reported (Grammatopoulos et al., 2001; Karteris et al., 2001; Karteris et al., 2000). Kovalovsky et al. (2002) described CRH-induced POMC expression via NUR transcription factors in AtT-20 cells through calcium-dependent and -independent pathways. Both pathways are initialized by $\mathrm{G}_{\mathrm{S}}$-dependent adenylate cyclase and transmitted by cAMP-dependent protein kinase signaling. Furthermore, both mechanisms lead to activation of the mitogenactivated protein kinase cascade and subsequent transactivation of NUR77, which stimulates POMC expression.

To further dissect CRH/CRHR1-dependent signaling mechanisms and to identify novel downstream targets that are potential molecular mediators of the neuroendocrine stress response, we analyzed for the first time CRH-elicited alterations within the proteome of corticotroph AtT-20 cells. 


\section{Methods}

\subsection{Cell culture}

AtT-20 cells were grown in Dulbecco's Modified Eagle's Medium supplemented with 2 mM Lglutamine, $10^{2} \mathrm{U} / \mathrm{ml}$ penicillin/streptomycin, $2.5 \mu \mathrm{g} / \mathrm{ml}$ amphotericin $\mathrm{B}$, and $10 \%(\mathrm{v} / \mathrm{v})$ fetal calf serum $(\mathrm{v} / \mathrm{v})$ and kept at $37^{\circ} \mathrm{C}$ in an atmosphere of $5 \% \mathrm{CO}_{2} \cdot 2 \cdot 10^{6}$ cells were seeded prior to hormone treatment. Hormone incubation was carried out in fresh medium two days after seeding with a concentration of $100 \mathrm{nM} \mathrm{CRH} \mathrm{(Bachem,} \mathrm{Bubendorf,} \mathrm{Switzerland)} \mathrm{in} \mathrm{two} \mathrm{distinct}$ experiments for $5 \mathrm{~min}, 10 \mathrm{~min}$ and $30 \mathrm{~min}$ (focus on early CRH response) as well as for $1 \mathrm{~h}, 2 \mathrm{~h}$ and $6 \mathrm{~h}$ (focus on late $\mathrm{CRH}$ response). The dose of $100 \mathrm{nM} \mathrm{CRH}$ was chosen as $100 \mathrm{nM} \mathrm{CRH}$ evokes a response in AtT-20 cells but is still below the concentration of maximal stimulation shown in transactivation assays (Peeters et al., 2004). For the 2D proteome analysis, control samples were treated with fresh medium without hormone supplementation for 30 min and $6 \mathrm{~h}$, respectively. After incubation, aliquots of the supernatant medium were collected from $30 \mathrm{~min}$ and $6 \mathrm{~h}$ control and hormone treated cells. ACTH analysis was performed to show the general effectiveness of the $\mathrm{CRH}$ treatment. Adherent cells were trypsinized and then washed with phosphate buffered saline.

\subsection{Radioimmunoassay}

ACTH in cell culture supernatant was analyzed by a radioimmunoassay method described elsewhere (Stalla et al., 1989). 


\subsection{Two dimensional polyacrylamide gel electrophoresis}

Two dimensional (2D) polyacrylamide gel electrophoresis analysis of proteome expression was carried out in triplicate. Protein extraction of $7 \cdot 10^{6}$ AtT-20 cells per sample was performed in 100 $\mu \mathrm{l}$ cell lysis buffer containing $40 \mathrm{mM}$ Tris base, $2 \%(\mathrm{w} / \mathrm{v}) \mathrm{NP}-40,5 \mathrm{mM}$ magnesium chloride, $4 \%$ (w/v) Chaps, $5 \mathrm{mM}$ dithiothreitol, $1 \mu \mathrm{M}$ pepstatin (Roche Diagnostics, Indianapolis, IN), Protease Inhibitor Cocktail Tablets (Roche Diagnostics), $500 \mathrm{U} / \mathrm{ml}$ endonuclease, and $50 \mu \mathrm{g} / \mathrm{ml}$ RNase. The cell suspension was incubated for $30 \mathrm{~min}$ at $37^{\circ} \mathrm{C}$ with occasional vortexing. Samples were subjected to electrophoresis with $300 \mu 1$ of isoelectric focusing buffer containing 2 M thiourea, $7 \mathrm{M}$ urea, 2\% (w/v) Chaps (Bio-Rad, Hercules, CA), 0.2\% (w/v) Bio-Lyte (BioRad), and $5 \mathrm{mM}$ dithiothreitol.

Apparatuses for 2D gel electrophoresis, IPG strips and scanners were from Bio-Rad. The total protein extracts were applied to $17 \mathrm{~cm}$ readymade IPG strips (nonlinear $\mathrm{pI}$ range 3-10). The strips were actively rehydrated for $12 \mathrm{~h}$ at $20^{\circ} \mathrm{C}$ and $50 \mathrm{~V}$. Voltage was ramped to $10,000 \mathrm{~V}$ and the focusing was performed until $60,000 \mathrm{Vh}$ was reached. Subsequently, the strips were equilibrated in equilibration buffer (50 mM Tris-HCl, $6 \mathrm{M}$ urea, 2\% (w/v) SDS, and 20\% (v/v) glycerol, $\mathrm{pH}$ 8.5) containing $2 \%(\mathrm{w} / \mathrm{v})$ dithiothreitol for $20 \mathrm{~min}$ followed by another equilibration for $20 \mathrm{~min}$ containing $2.5 \%(\mathrm{w} / \mathrm{v})$ iodoacetamide for in-gel reduction and carbamidomethylation. For the second dimension electrophoresis $12 \%(\mathrm{w} / \mathrm{v})$ sodium dodecyl sulphate polyacrylamide gels were used. For protein detection gels were first stained with ProQ Diamond (ProQ) (Molecular Probes, Eugene, OR) which visualizes phosphorylated proteins. The images were acquired with a Molecular Imager FX Pro fluorescence scanner. For subsequent total protein staining the same gels were stained with Coomassie Brilliant Blue G (CBB) (Sigma-Aldrich, St. Louis, MO) in 
colloidal solution (17\% (w/v) ammonium sulphate, 2\% (v/v) phosphoric acid, 34\% (v/v) methanol). Images were acquired by a GS-800 Densitometer.

\subsection{Analysis of the two dimensional electrophoresis images}

Both, ProQ and CBB-stained 2D gel images were analyzed with the PDQuest software (Bio-Rad) followed by manual examination. For each protein spot within the triplicate experimental setting, the median spot intensity and standard deviation were calculated. Protein spot intensities within single groups were analyzed with the one-way ANOVA and the Newman-Keuls post-testing. Candidate proteins with $P<0.05$ in the post-testing were registered as differentially regulated.

\subsection{In-gel protein digest and mass spectrometry analysis}

Protein spots of interest were excised from the gel using the Proteineer Sp automated spot cutter (Bruker Daltonics GmbH, Bremen, Germany). For cleanup and destaining gel spots were incubated for $30 \mathrm{~min}$ in $50 \mu \mathrm{l}$ of $1 \mathrm{mM}$ ammonium bicarbonate/acetonitrile (1:1). After drying the gel pieces, $5 \mu 1$ of $1 \mathrm{mM}$ ammonium bicarbonate solution containing $50 \mathrm{ng}$ of trypsin were added to each gel piece. Tryptic digestion was carried out overnight at $37^{\circ} \mathrm{C}$.

For nano-electrospray-ionisation mass spectrometry (nano-ESI-MS/MS) analysis the digested sample was dissolved in $12 \mu 10.1 \%(\mathrm{v} / \mathrm{v})$ formic acid. Each sample was injected with an HPLC system (Famos autosampler, Switchos micro column module and Ultimate micro pump; LCPackings-Dionex, Sunnyvale, CA) onto a C18 cartridge (300 $\mu \mathrm{m}$ x $1 \mathrm{~cm}$; LC-Packings-Dionex). After washing the cartridge with $0.1 \%(\mathrm{v} / \mathrm{v})$ formic acid for $15 \mathrm{~min}$, the peptides were eluted onto a Picofrit column (75 $\mu \mathrm{m} \times 5 \mathrm{~cm}$; New Objective, Woburn, MA) by applying a linear gradient of acetonitrile:water:formic acid (90:10:0.1) for $60 \mathrm{~min}$. The eluate was directly infused into an 
LCQ Deca XP Plus ion trap mass spectrometer (Thermo Electron, San Jose, CA). Each full scan was followed by a zoom scan and an MS/MS scan of the most intense signals.

For matrix assisted laser desorption ionization-time of flight mass spectrometry (MALDI-TOFMS) analysis, the samples were prepared by a dried droplet method on an AnchorChip MALDI Target $(600 \mu \mathrm{m}$ id; Bruker Daltonics) (Karas and Hillenkamp, 1988). $\alpha$-cyano-4hydroxycinnamic was dissolved in 30\% (v/v) acetonitrile and $0.07 \%(\mathrm{v} / \mathrm{v})$ trifluoroacetic acid to saturation. The matrix preparation was diluted tenfold in a 2:1 ethanol:acetone solution. Each digest sample was dissolved in $0.3 \%(\mathrm{v} / \mathrm{v})$ trifluoroacetic acid. $1.0 \mu \mathrm{l}$ of each sample mixture was spotted onto the AnchorChip. After the volume of the sample was reduced by $80 \%, 1.5 \mu 1$ of the prepared matrix solution were added to the spot. Each dried preparation was washed with $2.5 \mu 1$ of $0.3 \%(\mathrm{v} / \mathrm{v})$ trifluoroacetic acid. For calibration the Peptide Calibration Standard I (Bruker Daltonics) was applied. Peptide mass fingerprints were acquired using the Ultraflex TOF/TOF MALDI mass spectrometer (Bruker Daltonics).

\subsection{Protein identification}

Data from nano LC-ESI-MS/MS were analyzed with the Bioworks software (Thermo Electron). The individual MS/MS data were searched against NCBI non-redundant mouse protein database using the SEQUEST algorithm (Yates et al., 1995). SEQUEST search parameters were mass tolerances of $2 \mathrm{Da}$ for the precursor peptide mass, $1 \mathrm{Da}$ for MS/MS fragments and allowing two tryptic miscleavages. The searches were performed with a dynamic chemical modification of 16 Da for methionine oxidation and a static modification of $57 \mathrm{Da}$ for carbamidomethylation of cysteine residues. Proteins identified with at least two matched peptides were accepted as positive hits. 
MALDI-TOF-MS data analysis was carried out with Biotools software (Bruker Daltonics). For protein identification the database search program Mascot (Matrix Science, London, UK) was applied to identify proteins according to their tryptic mass fingerprints. The search was carried out against NCBI non-redundant and mouse protein database. Mascot search was set up with a 25 ppm parent mass tolerance and one possible tryptic miscleavage. Chemical modifications of methionine and cysteine residues were set as described above. Protein hits that were significant according to the Mascot score $(P<0.05)$ were accepted. All protein hits were further verified by reviewing the position of the spot for molecular weight and $\mathrm{pI}$ on the $2 \mathrm{D}$ image.

\subsection{Immunoblotting}

Immunoblotting was performed in independent material with five biological replicate samples per group. Protein was extracted by sonification in cell lysis buffer containing Protease Inhibitor Cocktail Tablets and Phosphatase Inhibitor Cocktail 1 and 2 (Sigma-Aldrich, St. Louis). Protein concentration was determined with the Bradford method (Bio-Rad) with bovine serum albumin as the protein standard.

To validate phosphoglycerate mutase 1 (PGAM1) and cAMP-dependent protein kinase type I- $\alpha$ regulatory subunit (PRKAR1A) modifications, protein extracts from $6 \mathrm{~h}$ control and $6 \mathrm{~h} \mathrm{CRH-}$ treated AtT-20 cells were analyzed. Briefly, $8 \mu \mathrm{g}$ of protein were separated on a $12 \%(\mathrm{w} / \mathrm{v}) \mathrm{SDS}$ gels and electrotransferred to a PVDF membrane. Non-specific binding sites were blocked for $1 \mathrm{~h}$ at room temperature in incubation buffer consisting of Tris buffered saline with $0.1 \%(\mathrm{v} / \mathrm{v})$ Tween and 5\% (w/v) non-fat dry milk, $\mathrm{pH}$ 7.5. Subsequently, membranes were treated in incubation buffer with the primary antibody (phosphoglycerate mutase, goat IgG, $1 \mu \mathrm{g} / \mathrm{ml}$, Acris Antibodies, Hiddenhausen, Germany; cAMP-dependent protein kinase type I- $\alpha$ regulatory 
subunit, rabbit IgG, 1:3000, Abgent, San Diego, CA; $\beta$-ACTIN, rabbit IgG, 1:1000, Abcam, Cambridge, UK) for $90 \mathrm{~min}$ at room temperature, followed by $60 \mathrm{~min}$ incubation at room temperature with secondary anti-rabbit or anti-goat horseradish peroxidase conjugate $(1: 4000$, GE Healthcare, Piscataway, NJ). Immuno-complexes were visualized by chemiluminescense (Millipore, Billerica, MA) and exposed to autoradiography films. To improve quantification the housekeeping protein $\beta$-ACTIN was used for normalization.

To validate proteasome subunit alpha type 3 (PSMA3), independent protein extracts from 10 min control and 10 min CRH-treated AtT-20 cells were analyzed by an isoelectric focusing immunoblotting assay. $5 \mu \mathrm{g}$ protein were diluted in $210 \mu \mathrm{l}$ isoelectric focusing buffer. Samples were applied to $11 \mathrm{~cm}$ readymade IPG strips (nonlinear pI range 3-10). Isoelectric focusing was carried out as described before. Separated proteins were blotted onto a PVDF membrane as described by (Towbin et al., 2001). Briefly, the IPG strips were fixed in 12\% (v/v) trichloroacetic acid, 3.5\% (w/v) sulfsalicylic acid for $1 \mathrm{~h}$ and washed twice with Milli-Q water for $30 \mathrm{~min}$. The strips were then placed on a glass plate and covered by a PVDF membrane. Four layers of filter paper sheets soaked with transfer buffer containing $4 \mathrm{M}$ guanidium chloride, $1 \mathrm{mg} / \mathrm{ml}$ dithiothreitol, $50 \mathrm{mM}$ Tris-HCl, $\mathrm{pH} 7.5$ and a second glass plate were placed on top. The setup was wrapped in a plastic foil and compressed at $\sim 30 \mathrm{~g} / \mathrm{cm}^{2}$. After $16 \mathrm{~h}$ transfer, the immunodetection was performed as described above (proteasome subunit alpha type 3, rabbit IgG, 1:250, Atlas Antibodies AB, Stockholm, Sweden; anti-rabbit horseradish peroxidase conjugate, 1:4000). Additionally, to demonstrate that alterations in PSMA3 are not due to quantitative changes conventional Western blots of PSMA3 and of the housekeeping protein $\beta$ ACTIN were performed following the protocols described above. 
Images were scanned and processed first in Adobe Photoshop to obtain gray scale illustration and then in ImageJ (http://rsb.info.nih.gov/ij/) to measure signal intensities. Quantification of total PGAM1, PRKAR1A and PSMA3 expression was performed by comparison to the housekeeping protein $\beta$-ACTIN. PSMA3 modification was evaluated by the ratio of the protein isoform intensities. The statistical analysis was carried out with the $t$-test. The difference was considered to be significant when $P<0.05$.

\subsection{Real-time quantitative reverse transcription PCR}

Total RNA was isolated from AtT-20 cells after 10 min and 6 h CRH stimulations as well as from appropriate control cells (10 min and $6 \mathrm{~h}$ CRH control). Each group consisted of five experimental independent subjects. RNA was extracted using TRIzol reagent (Molecular Probes) following the manufacturer's instructions. cDNA was synthesized from 300 ng total RNA using the Superscript II Reverse Transcriptase (Molecular Probes). PCR amplifications were performed using the LightCycler 2.0 Real-Time PCR Systems and the LightCycler FastStart DNA Master SYBR Green kit (Roche) according to the manufactures protocol. The primers used for the quantification are listed in Table 1. Quantification was carried out using a dilution standard from pooled sample probes. Relative expression was determined by normalization to hypoxanthine guanine phosphoribosyl transferase (HPRT). The statistical analysis was carried out with the $t$ test. The difference was considered to be significant with a mean change of at least $25 \%$ and a $P$ $<0.05$.

\section{Table 1}




\section{Results}

We analyzed the proteome of AtT-20 cells following different durations of continuous CRH exposure to identify CRH-dependent alterations in protein levels and posttranslational modifications. To control for the efficacy of treatment we exemplarily determined ACTH levels in cell culture supernatants of vehicle and CRH treated AtT-20 cells following 30 min and $6 \mathrm{~h}$ incubation. A significant increase of ACTH was detectable after 30 min of $\mathrm{CRH}$ treatment. Although vehicle treated AtT-20 cells displayed accumulated background ACTH release after $6 \mathrm{~h}$ of treatment, this was clearly distinguishable from the CRH-induced ACTH response (Figure 1).

\section{$\rightarrow$ Figure 1}

Differential analysis of cytosolic proteins of CRH-treated AtT-20 cells by 2D gel electrophoresis revealed a multitude of protein spots significantly regulated in spot intensity following different durations of $\mathrm{CRH}$ treatment. Intensity differences were found in both Coomassie Brilliant Blue G (CBB) and in ProQ Diamond (ProQ) stained gels. 2D gels were first analyzed with the PDQuest software and than manually reviewed to extract the most reliable targets differentially altered upon CRH treatment. Target proteins were identified by nano-ESI-MS/MS or MALDI-TOF-MS, respectively. Results of the mass spectrometry analysis are given in Table 2 . We identified 8 proteins in response to short term and 11 proteins in response to long term CRH treatment that were significantly regulated (Table 3 and Table 4). Identified proteins participate in diverse biological processes such as transcription and translation, protein fate (protein folding, degradation), signal transduction and metabolism (Table 3 and Table 4). 
To further confirm the results of the global proteome analysis, we chose representatives of the early (proteasome subunit alpha type 3, PSMA3) as well as late $\mathrm{CRH}$ responsive proteins (phosphoglycerate mutase 1, PGAM1; cAMP-dependent protein kinase type I- $\alpha$ regulatory subunit, PRKAR1A) for validation in independent material using immunoblotting analysis.

\section{$\rightarrow$ Table 3 and 4}

In ProQ-stained 2D gels a difference in intensities of PSMA3 spots was detected after 5 min, 10 min and 30 min of CRH treatment compared to control samples (Figure 2A-C). The intensity of the protein with the lower pI decreased significantly following short term $\mathrm{CRH}$ incubation compared to the control, whereas the intensity of the protein with the higher pI was inversely regulated (Table 3, Figure 2B, C). Due to high variance the regulation of the higher pI spot was statistically not significant. Altogether, we detected three isoforms of PSMA3 in our 2D gel analysis. In addition to the two isoforms that showed regulation in the phosphorylation specific ProQ staining in the course of early $\mathrm{CRH}$ response, a third isoform with a higher $\mathrm{pI}$ was detected. This isoform showed a down regulation in the course of the late $\mathrm{CRH}$ response (Table 4). The difference of PSMA3 that was detected following short term $\mathrm{CRH}$ treatment was validated in independent material following $10 \mathrm{~min}$ of $\mathrm{CRH}$ incubation (Figure 3A, B). Isoelectric focusing using IPG strips and subsequent Western blot analysis resulted in five bands in the lower pI range. Upon position within the IPG strip we assume that two of the bands (Figure 3A, band 1 and 2) presumably correspond to the spots that were detected as regulated within the 2D gels after short term $\mathrm{CRH}$ treatment (Figure 2B, C, spot 1 and 2). Furthermore, we suppose that bands A-C represent PSMA3 isoforms that we did not identify before in the $2 \mathrm{D}$ analysis. Quantification 
of PSMA3 variants within the immunoblot revealed a significant change in the ratio of the PSMA3 isoforms 1 and 2 supporting the results of the 2D gel analysis (Figure 3B). Additionally, we found significant regulation regarding the PSMA3 isoform represented by band C whereas no regulation in ratio was observed for isoforms $\mathrm{A}$ and $\mathrm{B}$. A conventional Western blot of PSMA3 together with the housekeeping protein $\beta$-ACTIN demonstrated that the total amount of PSMA3 was not altered by 10 min of CRH treatment (Figure 3C, D).

\section{$\rightarrow$ Figure 2, Figure 3}

For PGAM1 we identified differences in spot intensities in CBB-stained gels following long term CRH treatment (Figure 4A-C). Under control conditions only a single protein spot was detectable (Figure 4B). However, after $2 \mathrm{~h}$ and $6 \mathrm{~h}$ of $\mathrm{CRH}$ incubation, an additional PGAM1 spot with a lower pI appeared (Table 4; Figure 4C). Independent confirmation by conventional Western blot analysis of AtT-20 cells treated with CRH for $6 \mathrm{~h}$, detected PGAM1 at $29 \mathrm{kDa}$ (Figure 5A). Using $\beta$-ACTIN as a housekeeping protein we were able to demonstrate a significant increase of PGAM1 following $6 \mathrm{~h} \mathrm{CRH} \mathrm{treatment} \mathrm{(Figure} \mathrm{5B).} \mathrm{The} \mathrm{anti-PGAM1} \mathrm{antibody} \mathrm{does} \mathrm{not}$ discriminate specific isoforms. Thus the increase of $60 \%$ includes all isoforms of PGAM1.

\section{$\rightarrow$ Figure 4, Figure 5}

2D gel analysis and CBB staining detected two isoforms of PRKAR1A (Figure 4A, D, E). Both isoforms were increased following $2 \mathrm{~h}$ and $6 \mathrm{~h}$ of $\mathrm{CRH}$ incubation (Table 4, Figure 4). However, the observed increase was statistically significant only for the protein spot with the lower pI. To 
validate the quantitative increase of PRKAR1A found in the 2D analysis, we performed Western blot analysis of the same independent material, which was used for validation of PGAM1 (Figure 5A, C). PRKAR1A was detected at $43 \mathrm{kDa}$ (Figure 5A) and quantification of Western blot results revealed a 59\% up regulation of PRKAR1A following $6 \mathrm{~h} \mathrm{CRH}$ treatment confirming the findings from the 2D gel analysis (Figure 5C). Again, the primary anti-PRKAR1A antibody does not discriminate specific isoforms, and the observed signal increase in the Western blot experiment reflects all PRKAR1A isoforms.

In order to correlate alterations in protein expression with changes of mRNA level, real-time quantitative reverse transcription PCR (qRT-PCR) was performed for all candidates. For the early $\mathrm{CRH}$ response, following $10 \mathrm{~min} \mathrm{CRH}$ incubation, no alterations in gene expression were detected (data not shown). For all candidates that showed alterations during the late CRH response, including the independently confirmed candidates PSMA3, PGAM1 and PRKAR1A, qRT-PCR was performed using RNA from AtT-20 cells after $6 \mathrm{~h}$ of CRH treatment. An mRNA mean change of at least $25 \%$ and a $P<0.05$ of the appropriate $t$-test were considered to reflect a significant effect of $\mathrm{CRH}$ on gene expression (Figure 6). In the case of our independently confirmed candidates, we did not detect a significant change of Psma3 mRNA after $6 \mathrm{~h}$ of CRH treatment, which strengthens the assumption that PSMA3 is only posttranslational modified in the course of $\mathrm{CRH}$ exposure. However, both PGAM1 and PRKAR1A showed a significant increase in mRNA expression consistent with our findings in the 2D and Western blot analyses.

\section{$\rightarrow$ Figure 6}




\section{Discussion}

AtT-20 cells are an intermediate pituitary corticotroph cell line, which has proven to be an ideal cellular system to study molecular signal transduction mechanisms (Abbud et al., 2004). In particular, signaling networks related to CRHR1 have been successfully dissected in this cell line (Kageyama et al., 2007; Peeters et al., 2004; Kovalovsky et al., 2002). Nevertheless, CRHmediated changes in transcription, protein expression and modification are not implicitly transferable to physiological effects in pituitary corticotroph cells. Here, we present for the first time a differential proteome analysis of CRH-treated AtT-20 cells. As this corticotroph cell line solely expresses CRHR1 and not CRHR2 the identified candidates are specific targets of the signal transduction cascade downstream of CRH receptor type 1 (Peeters et al., 2004).

We analyzed the proteome upon CRH stimulation by $2 \mathrm{D}$ gel electrophoresis. In total we observed 18 different proteins with significantly altered spot intensities in the $2 \mathrm{D}$ gel analysis either due to changes in their expression level or due to altered posttranslational modification. Alterations in the distribution of proteins within the $2 \mathrm{D}$ gel might be caused by quantitative or qualitative changes of the respective protein. As we do not know the all over distribution of all existing isoforms of a given protein we cannot definitely conclude a quantitative or qualitative alteration just by the $2 \mathrm{D}$ analysis. The proteins we identified are potential downstream targets of major signaling cascades known to be stimulated by CRH in AtT-20 cells such as pathways related to cAMP/PKA, voltage-dependent calcium channels or MAP kinases (Kovalovsky et al., 2002). None of the identified proteins has been previously identified in an mRNA expression profiling experiment performed under comparable conditions in AtT-20 cells (Peeters et al., 2004). The identified proteins are related to diverse biological processes and pathways, which by and large 
have not been previously linked to CRHR1 signaling. The functional relevance of the identified proteins and related pathways will be discussed below.

The analysis of the AtT-20 proteome at the early time points (5 min, $10 \mathrm{~min}$ and $30 \mathrm{~min}$ ) aimed specifically at the revelation of proteins posttranslationally modified in response to $\mathrm{CRH}$ treatment. Accordingly, all proteins that were identified to be modified in the course of the early $\mathrm{CRH}$ response did not show any change in mRNA levels after $10 \mathrm{~min} \mathrm{CRH}$ incubation as demonstrated by qRT-PCR (data not shown). The 2D proteome analysis following $1 \mathrm{~h}, 2 \mathrm{~h}$ and 6 h CRH treatments were performed with the objective to identify alterations in protein expression levels. Our results show, however, that based on CBB and ProQ gel staining the identified protein expression level differences do not correlate with mRNA changes (GOT1, FKBP1A, REXO2, PSMA3, NME1 and PGK1) suggesting posttranslational modifications as a cause for these protein differences.

In AtT-20 cells, ligand-mediated activation of CRHR1 leads to an increase in cAMP levels and activation of the cAMP-dependent protein kinase (protein kinase A, PKA), which then initiates downstream signal transduction pathways (Kovalovsky et al., 2002). The serine/threonine kinase PKA is a tetrameric holoenzyme composed of two catalytic and two regulatory subunits. In the presence of cAMP the subunits dissociate into a regulatory subunit dimer and two free catalytically active subunits. In our proteome analysis we identified two spots, which were upregulated after $2 \mathrm{~h}$ and $6 \mathrm{~h}$ and were identified as the regulatory subunit PRKAR1A. In accordance with the presence of several phosphoserine sites in PRKAR1A (Villen et al., 2007), the lower pI spot was also detected in ProQ-stained gels indicating a phosphorylated state of the protein (data not shown). The increased protein and mRNA expression levels of the regulatory 
PKA subunit might reflect an adaptation to the continuous CRH-mediated stimulation of the immediate CRHR1 downstream effector PKA. Whether the increased expression of PRKAR1A represents a cellular mechanism to counteract persisting cAMP production needs further investigation.

Several candidates indicate that $\mathrm{CRH}$ stimulation has a rapid (EEF1D, PSMA3, PSMC2) and lasting (PSMA3, ARBP, FKBP1A, GOT1) impact on the cellular machinery regulating protein synthesis and fate and might be essential for the stimulus-dependent induction or repression of CRHR1 downstream targets. For instance, PSMA3 was identified as significantly regulated after 10 min of CRH incubation as observed by a change in the relative abundance of two isoforms in the $2 \mathrm{D}$ analysis following short $\mathrm{CRH}$ treatment. Although these isoforms are regulated in opposite directions we cannot exclude that other isoforms might be involved as well, as a third isoform of the protein was regulated after $10 \mathrm{CRH}$ incubation as shown by the isoelectric focusing immunoblotting experiment. Furthermore, an additional PSMA3 isoform at higher pI was regulated after $1 \mathrm{~h}$ and $2 \mathrm{~h}$ of $\mathrm{CRH}$ incubation as shown by the $2 \mathrm{D}$ analysis. The differently phosphorylated isoforms are in accordance with two possible phosphoserine sites that have been reported for PSMA3 (Castano et al., 1996). No regulation of PSMA3 mRNA levels in the early and late CRH response as well as of total PSMA3 protein in the early $\mathrm{CRH}$ response experiment were observed. These findings suggest that the impact of early and late CRH signaling on PSMA3 depends on posttranslational modifications of the protein rather than on altered protein levels. However, we cannot fully eliminate the possibility that the mRNA levels were changed at other intermediate time points. The proteasome is a $26 \mathrm{~S}$ multiprotein complex composed of a $20 \mathrm{~S}$ core catalytic complex and two 19S regulatory subunits. The $20 \mathrm{~S}$ core is a hollow cylinder formed by two central $\beta$-subunit rings stacked between two $\alpha$-subunit rings. Each $\beta$-subunit ring 
contains three different proteolytic sites that face the center of the core, while the $\alpha$-subunit ring provides a narrow gated channel to these active sites. The 19S regulatory subunits function as cap on either end of the proteolytic core (Baumeister et al., 1998). PSMA3 belongs to the $\alpha$-subunit ring and has no catalytic function. Probably, it is involved in the translocation of substrates into the catalytic cavity (Voges et al., 1999). Modifications in the phosphorylation status most likely do not alter the proteolytic activity but might be important in the control of proteasome interaction with other proteins (Ludemann et al., 1993). As another integral component of the proteasome we found the 26S subunit, ATPase 2 (PSMC2) modified after 30 min of $\mathrm{CRH}$ exposure. Also the eukaryotic translation elongation factor $1 \delta$ (EEF1D), which was detected to be modified already after 5 min of $\mathrm{CRH}$ treatment, points towards a rapid modulation of mechanisms related to protein synthesis. In agreement with our studies in AtT-20 cells, EEF1D phosphorylated at Ser162 has been recently identified within a phosphoproteome analysis of the human pituitary (Beranova-Giorgianni et al., 2006). Along these lines, we identified in the late CRH response experiment an increase of two spots of the acidic ribosomal protein P0 (ARBP) after $1 \mathrm{~h}, 2 \mathrm{~h}$ and $6 \mathrm{~h}$ of CRH stimulation compared to control treatment. The mRNA analysis confirmed a significant increase in the mRNA expression after $6 \mathrm{~h}$ of $\mathrm{CRH}$ exposure. ARBP contains two potential phosphoserine residues and was shown to be phosphorylated at Ser304 in the human pituitary (Beranova-Giorgianni et al., 2006). Phosphorylation-dependent control of ARBP activity plays an important role in guiding the elongation process in the course of protein synthesis (Ballesta et al., 1999). Moreover, the identification of a decrease in the FK506 binding protein 1a (FKBP1A) suggests that molecules involved in protein maturation are also affected. FKBP1A catalyzes the cis-trans isomerization of proline imidic peptide bonds and accelerates the folding of proteins. Again, the mRNA quantification rather favors a posttranslational 
modification as causative for the decreased spot intensity. Identification of a modification of the glutamate oxalacetate transaminase-1 (GOT1) after $2 \mathrm{~h} \mathrm{CRH}$ treatment might also indicate an activation of protein turnover.

A decrease of the heterogeneous nuclear ribonucleoprotein A2/B1 (HNRPA2B1) protein spot in ProQ-stained gels suggests that $\mathrm{CRH}$ stimulation also has an impact on RNA processing. HNRPA2B1 was decreased after $2 \mathrm{~h}$ and $6 \mathrm{~h}$ of $\mathrm{CRH}$ incubation. The $\mathrm{A} 2$ and $\mathrm{B} 1$ isoforms are different splice variants of the Hnrnpa2b1 gene with an additional mini-exon of 36 nucleotides in the B1 isoform. From our MS data we were unable to determine the precise nature of the isoform variant. Heterogeneous nuclear ribonucleoproteins are involved in pre-mRNA processing by binding cooperatively to nascent pre-mRNA introns (Dreyfuss et al., 1993) and have been reported to have functional relevance in hormonal regulation of alternative splicing (Wu et al., 2005). The observed protein alteration might be caused by either protein degradation or posttranslational modification. However, the qRT-PCR revealed a significant increase of the mRNA after $6 \mathrm{~h}$ of $\mathrm{CRH}$ treatment pointing towards quantitative regulation of this target.

The regulation of PGAM1, phosphoglycerate kinase 1 (PGK1) and expressed in non-metastatic cells 1 protein (NME1) suggest that CRH treatment either affects glycolysis or gluconeogenesis. We found a striking modification of PGAM1 in CBB-stained gels, which was confirmed in the immunoblotting and qRT-PCR experiments indicating an increase of total PGAM1 after $6 \mathrm{~h}$ of CRH treatment. PGAM1 is involved in glycolysis and gluconeogenesis. The enzyme catalyzes the interconversion between 3-phosphoglycerate and 2-phosphoglycerate whereas it dephosphorylates 2,3-bisphosphoglycerate either to 2-phosphoglycerate or 3-phosphoglycerate and maintains the phospho group on a histidine residue within the catalytic cleft (Bond et al., 2001). Subsequently, the phosphorylated enzyme converts 3-phosphoglcerate or 2- 
phosphoglycerate to 2,3-bisphosphoglycerate by transferring the phospho group to the substrate. We assume that the shift of PGAM1 towards the lower pI represents the activated intermediate of the enzyme that possesses a phosphohistidine residue. It has been reported that PGAM1 can also be activated by $\mathrm{dCTP}$ in the presence of NME1, a nucleoside diphosphate kinase (Engel et al., 2004). In our analysis we detected a regulation of NME1 at the protein expression level before PGAM1 appears to be modified. An activation of PGAM1 via NME1 in the course of CRH signaling is also possible. Besides PGAM1 we identified PGK1, another enzyme involved in glycolysis, to be modified after $6 \mathrm{~h}$ treatment.

A candidate probably more directly linked with CRHR1 function and its role in HPA axis regulation is the stress-induced-phosphoprotein 1 (STIP1). STIP1, also known as HSP70/HSP90organizing protein (HOP), is modified within minutes following CRH stimulation. STIP1 is a cochaperone that mediates the association of HSP70 and HSP90 and thereby influences the maturation and activation of steroid hormone receptors such as the glucocorticoid receptor (Odunuga et al., 2004; Morishima et al., 2000). The final effectors of the endocrine stress response elicited by $\mathrm{CRH}$ are glucocorticoids, which beside their action on numerous physiological processes also mediate a negative feedback to the pituitary in order to terminate the endocrine stress response. Therefore, a direct impact of CRH-mediated signaling on glucocorticoid receptor activity in AtT-20 cells and thus most likely also in the pituitary, could resemble a novel $\mathrm{CRH}-d e p e n d e n t$ mechanism involved in negative feedback regulation of the HPA axis.

Identification of the spermidine synthase (SRM) supports the role of $\mathrm{CRH}$ as a key mediator of the cellular stress response. SRM was found to be modified within the early CRH response. The enzyme that is involved in the synthesis of the polyamines spermidine and spermine (Pegg et al., 
1995), appeared at three positions on the 2D gel with approximately the same molecular weight but different pIs. In the acute incubation experiment the protein with the lower pI decreased in intensity during the course of incubation whereas the protein with the higher $\mathrm{pI}$ increased. The enzyme's products, the natural polyamine cations spermidine and spermine, have multiple functions in cell growth and maintenance of cell viability (Seiler and Raul, 2005) as well as neuroprotection and neurotoxicity (Janne et al., 2005; Takano et al., 2005). In the mammalian brain, polyamines are present at high concentrations and their biosynthesis is induced by stressful stimuli such as physical, emotional or hormonal stressors suggesting that an appropriate regulation of this polyamine stress response might be relevant for neuronal function and behavioral adaptation to stress (Gilad and Gilad, 2003).

A growing body of evidence supports a functional interaction between the CRH system and noradrenergic, dopaminergic as well as serotonergic neurotransmission (Summers et al., 2003; Linthorst et al., 2002; Koob, 1999). In this context, the decrease of a protein spot corresponding to the enzyme sepiapterin reductase (SPR) within $5 \mathrm{~min}$ after CRH stimulation is of interest. SPR catalyzes the final step in the biosynthesis of tetrahydrobiopterin. $\left(\mathrm{BH}_{4}\right) \cdot \mathrm{BH}_{4}$ is an essential cofactor for several enzymes including tyrosine hydroxylase and tryptophan hydroxylase, which are the rate limiting enzymes in the biosynthesis of catecholamines and indolamines (Nagatsu and Ichinose, 1999). Mutations in the human $S P R$ gene or deficiency in $\mathrm{BH}_{4}$ cause severe neurotransmitter deficiencies and lead to pathological states including convulsions, movement disorders and depression (Steinberger et al., 2004; Bonafe et al., 2001; van Amsterdam and Opperhuizen, 1999). Moreover, McHugh and colleagues (2008) have recently demonstrated a strong upregulation of SPR in embryonic stem cell-derived neural cultures in response to the 
antidepressant paroxetine further supporting a link between $\mathrm{BH}_{4}$ levels and mood control as well as antidepressant action.

Finally, a number of proteins were identified whose connection to CRHR1 signaling is unclear. For instance, we observed increased spot intensity of the hydroxymethyl-glutaryl-CoA synthase in CBB-stained images. Supporting these findings we could also demonstrate an increase in mRNA levels after CRH treatment. The enzyme is involved in the first step of the synthesis of cholesterol. Similarly, a protein spot representing nudix-type motif 5 (NUDT5) is decreased in signal intensity in ProQ-stained gels after 10 min of CRH stimulation. NUDT5 hydrolyzes ADPsugars, especially ADP-ribose. Free ADP-riboses are produced during the processes of degrading protein bound mono- or poly-ADP-riboses, or cyclic ADP-riboses. Free ADP-ribose and its derivatives are highly reactive molecules that cause non-enzymatic mono-ADP-ribosylation of proteins leading to toxic effects (Jacobson et al., 1994). Through enzymatic hydrolysis NUDT5 removes free reactive ADP-ribose and has probably a function as house cleaning enzyme to remove highly reactive free ADP-ribose molecules. The Niemann-Pick type C2 (NPC2) protein, which was found to be modified during the early $\mathrm{CRH}$ response, is a secreted soluble protein and specifically binds cholesterol with high affinity (Ko et al., 2003). Mutation of the protein leads to accumulation of cholesterol and other lipids in aberrant compartments causing substantial cell death, particularly in the cerebellum that accounts for the Niemann-Pick Type C autosomalrecessive disorder (Liscum and Faust, 1987). NPC2 plays a role in the regulation of cellular cholesterol homeostasis (Frolov et al., 2003).

In conclusion, we studied the effect of $\mathrm{CRH}$ on protein expression and posttranslational modification of proteins in AtT-20 cells using for the first time a proteome profiling approach. Even though the experimental setup did not allow to distinguish between primary and secondary 
effects induced by $\mathrm{CRH}$, the present work provides valuable insights into the temporal course of CRH-mediated signaling mechanisms on the protein level. We were able to unravel several novel targets previously not linked to $\mathrm{CRH} / \mathrm{CRHR} 1$ signaling. Further in-depth investigation of the functional relevance of the identified proteins and their modifications will add to our understanding of CRH-mediated signaling and HPA axis homeostasis. 


\section{Acknowledgements}

We thank Johanna Stalla for experimental support with the ACTH radioimmunoassays. This work was partially supported by the Bundesministerium für Bildung und Forschung within the framework of the NGFN2 (01GS0481) and by the Fonds der Chemischen Industrie. 


\begin{abstract}
Abbreviations
2D: two dimensional, ACTH: adrenocorticotropic hormone, AtT-20 cells: mouse pituitary gland tumor cell line, ARBP: acidic ribosomal protein P0, BH4: tetrahydrobiopterin, CBB: Coomassie Brilliant Blue G, CRH: corticotropin-releasing hormone, CRHR: CRH receptor, EEF1D: eukaryotic translation elongation factor $1 \delta$, FKBP1A: FK506 binding protein 1a, HNRPA2B1: heterogeneous nuclear ribonucleoprotein A2/B1, HPA: hypothalamus-pituitary-adrenocortical, HPRT: hypoxanthine guanine phosphoribosyl transferase, MALDI-TOF-MS: matrix assisted laser desorption ionization-time of flight mass spectrometry, nano-ESI-MS/MS: nanoelectrospray-ionisation mass spectrometry, NME1: expressed in non-metastatic cells 1 protein, NUDT5: nudix-type motif 5, PGAM1: phosphoglycerate mutase 1, PKA: protein kinase A, Pomc: proopiomelanocortin, PRKAR1A: cAMP-dependent protein kinase type I- $\alpha$ regulatory subunit, ProQ: ProQ Diamond, PSMA3: proteasome subunit alpha type 3, qRT-PCR: real-time quantitative reverse transcription PCR, SDS-PAGE: sodium dodecyl sulphate-polyacrylamide gel electrophoresis, SPR: sepiapterin reductase, SRM: spermidine synthase, STIP1: stress-induced phosphoprotein 1 .
\end{abstract}




\section{Reference List}

Abbud, R.A., Kelleher, R., Melmed, S., 2004. Cell-specific pituitary gene expression profiles after treatment with leukemia inhibitory factor reveal novel modulators for proopiomelanocortin expression. Endocrinology 145, 867-880.

Ballesta, J.P., Rodriguez-Gabriel, M.A., Bou, G., Briones, E., Zambrano, R., Remacha, M., 1999. Phosphorylation of the yeast ribosomal stalk. Functional effects and enzymes involved in the process. FEMS Microbiol. Rev. 23, 537-550.

Baumeister, W., Walz, J., Zuhl, F., Seemuller, E., 1998. The proteasome: paradigm of a selfcompartmentalizing protease. Cell 92, 367-380.

Beranova-Giorgianni, S., Zhao, Y., Desiderio, D.M., Giorgianni, F., 2006. Phosphoproteomic analysis of the human pituitary. Pituitary. 9, 109-120.

Bonafe, L., Blau, N., Burlina, A.P., Romstad, A., Guttler, F., Burlina, A.B., 2001. Treatable neurotransmitter deficiency in mild phenylketonuria. Neurology 57, 908-911.

Bond, C.S., White, M.F., Hunter, W.N., 2001. High resolution structure of the phosphohistidineactivated form of Escherichia coli cofactor-dependent phosphoglycerate mutase. J. Biol. Chem. 276, 3247-3253.

Castano, J.G., Mahillo, E., Arizti, P., Arribas, J., 1996. Phosphorylation of C8 and C9 subunits of the multicatalytic proteinase by casein kinase II and identification of the C8 phosphorylation sites by direct mutagenesis. Biochemistry 35, 3782-3789. 
Coplan, J.D., Andrews, M.W., Rosenblum, L.A., Owens, M.J., Friedman, S., Gorman, J.M., Nemeroff, C.B., 1996. Persistent elevations of cerebrospinal fluid concentrations of corticotropin-releasing factor in adult nonhuman primates exposed to early-life stressors: implications for the pathophysiology of mood and anxiety disorders. Proc. Natl. Acad. Sci. U. S. A 93, 1619-1623.

de Kloet, E.R., Joels, M., Holsboer, F., 2005. Stress and the brain: from adaptation to disease. Nat. Rev. Neurosci. 6, 463-475.

Deussing, J.M., Wurst, W., 2005. Dissecting the genetic effect of the CRH system on anxiety and stress-related behaviour. C. R. Biol. 328, 199-212.

Dreyfuss, G., Matunis, M.J., Pinol-Roma, S., Burd, C.G., 1993. hnRNP proteins and the biogenesis of mRNA. Annu. Rev. Biochem. 62, 289-321.

Engel, M., Mazurek, S., Eigenbrodt, E., Welter, C., 2004. Phosphoglycerate mutase-derived polypeptide inhibits glycolytic flux and induces cell growth arrest in tumor cell lines. J. Biol. Chem. 279, 35803-35812.

Frolov, A., Zielinski, S.E., Crowley, J.R., Dudley-Rucker, N., Schaffer, J.E., Ory, D.S., 2003. NPC1 and NPC2 regulate cellular cholesterol homeostasis through generation of low density lipoprotein cholesterol-derived oxysterols. J. Biol. Chem. 278, 25517-25525.

Gilad, G.M., Gilad, V.H., 2003. Overview of the brain polyamine-stress-response: regulation, development, and modulation by lithium and role in cell survival. Cell Mol. Neurobiol. 23, 637649. 
Grammatopoulos, D., Milton, N.G., Hillhouse, E.W., 1994. The human myometrial CRH receptor: G proteins and second messengers. Mol. Cell Endocrinol. 99, 245-250.

Grammatopoulos, D.K., Randeva, H.S., Levine, M.A., Kanellopoulou, K.A., Hillhouse, E.W., 2001. Rat cerebral cortex corticotropin-releasing hormone receptors: evidence for receptor coupling to multiple G-proteins. J. Neurochem. 76, 509-519.

Holsboer, F., 1999. The rationale for corticotropin-releasing hormone receptor (CRH-R) antagonists to treat depression and anxiety. J. Psychiatr. Res. 33, 181-214.

Holsboer, F., 2000. The corticosteroid receptor hypothesis of depression. Neuropsychopharmacology 23, 477-501.

Jacobson, E.L., Cervantes-Laurean, D., Jacobson, M.K., 1994. Glycation of proteins by ADPribose. Mol. Cell Biochem. 138, 207-212.

Janne, J., Alhonen, L., Keinanen, T.A., Pietila, M., Uimari, A., Pirinen, E., Hyvonen, M.T., Jarvinen, A., 2005. Animal disease models generated by genetic engineering of polyamine metabolism. J. Cell Mol. Med. 9, 865-882.

Kageyama, K., Hanada, K., Moriyama, T., Imaizumi, T., Satoh, K., Suda, T., 2007. Differential regulation of CREB and ERK phosphorylation through corticotropin-releasing factor receptors type 1 and 2 in AtT-20 and A7r5 cells. Mol. Cell Endocrinol. 263, 90-102.

Karas, M., Hillenkamp, F., 1988. Laser desorption ionization of proteins with molecular masses exceeding 10,000 daltons. Anal. Chem. 60, 2299-2301. 
Karteris, E., Grammatopoulos, D., Randeva, H., Hillhouse, E.W., 2000. Signal transduction characteristics of the corticotropin-releasing hormone receptors in the feto-placental unit. J. Clin. Endocrinol. Metab 85, 1989-1996.

Karteris, E., Randeva, H.S., Grammatopoulos, D.K., Jaffe, R.B., Hillhouse, E.W., 2001. Expression and coupling characteristics of the $\mathrm{CRH}$ and orexin type 2 receptors in human fetal adrenals. J. Clin. Endocrinol. Metab 86, 4512-4519.

Keck, M.E., Holsboer, F., 2001. Hyperactivity of CRH neuronal circuits as a target for therapeutic interventions in affective disorders. Peptides 22, 835-844.

Ko, D.C., Binkley, J., Sidow, A., Scott, M.P., 2003. The integrity of a cholesterol-binding pocket in Niemann-Pick C2 protein is necessary to control lysosome cholesterol levels. Proc. Natl. Acad. Sci. U. S. A 100, 2518-2525.

Koob, G.F., 1999. Corticotropin-releasing factor, norepinephrine, and stress. Biol. Psychiatry 46, 1167-1180.

Kovalovsky, D., Refojo, D., Liberman, A.C., Hochbaum, D., Pereda, M.P., Coso, O.A., Stalla, G.K., Holsboer, F., Arzt, E., 2002. Activation and induction of NUR77/NURR1 in corticotrophs by $\mathrm{CRH} / \mathrm{cAMP}$ : involvement of calcium, protein kinase A, and MAPK pathways. Mol. Endocrinol. 16, 1638-1651.

Linthorst, A.C., Penalva, R.G., Flachskamm, C., Holsboer, F., Reul, J.M., 2002. Forced swim stress activates rat hippocampal serotonergic neurotransmission involving a corticotropinreleasing hormone receptor-dependent mechanism. Eur. J. Neurosci. 16, 2441-2452. 
Liscum, L., Faust, J.R., 1987. Low density lipoprotein (LDL)-mediated suppression of cholesterol synthesis and LDL uptake is defective in Niemann-Pick type C fibroblasts. J. Biol. Chem. 262, 17002-17008.

Lovenberg, T.W., Chalmers, D.T., Liu, C., De Souza, E.B., 1995. CRF2 alpha and CRF2 beta receptor mRNAs are differentially distributed between the rat central nervous system and peripheral tissues. Endocrinology 136, 4139-4142.

Ludemann, R., Lerea, K.M., Etlinger, J.D., 1993. Copurification of casein kinase II with $20 \mathrm{~S}$ proteasomes and phosphorylation of a 30-kDa proteasome subunit. J. Biol. Chem. 268, 1741317417.

McHugh, P.C., Rogers, G.R., Loudon, B., Glubb, D.M., Joyce, P.R., Kennedy, M.A., 2008. Proteomic analysis of embryonic stem cell-derived neural cells exposed to the antidepressant paroxetine. J. Neurosci. Res. 86, 306-316.

Morishima, Y., Kanelakis, K.C., Silverstein, A.M., Dittmar, K.D., Estrada, L., Pratt, W.B., 2000. The Hsp organizer protein hop enhances the rate of but is not essential for glucocorticoid receptor folding by the multiprotein Hsp90-based chaperone system. J. Biol. Chem. 275, 6894-6900.

Nagatsu, T., Ichinose, H., 1999. Regulation of pteridine-requiring enzymes by the cofactor tetrahydrobiopterin. Mol. Neurobiol. 19, 79-96.

Nemeroff, C.B., Widerlov, E., Bissette, G., Walleus, H., Karlsson, I., Eklund, K., Kilts, C.D., Loosen, P.T., Vale, W., 1984. Elevated concentrations of CSF corticotropin-releasing factor-like immunoreactivity in depressed patients. Science 226, 1342-1344. 
Odunuga, O.O., Longshaw, V.M., Blatch, G.L., 2004. Hop: more than an Hsp70/Hsp90 adaptor protein. Bioessays 26, 1058-1068.

Peeters, P.J., Gohlmann, H.W., van, d.W., I, Swagemakers, S.M., Bijnens, L., Kass, S.U., Steckler, T., 2004. Transcriptional response to corticotropin-releasing factor in AtT-20 cells. Mol. Pharmacol. 66, 1083-1092.

Pegg, A.E., Poulin, R., Coward, J.K., 1995. Use of aminopropyltransferase inhibitors and of nonmetabolizable analogs to study polyamine regulation and function. Int. J. Biochem. Cell Biol. 27, 425-442.

Potter, E., Sutton, S., Donaldson, C., Chen, R., Perrin, M., Lewis, K., Sawchenko, P.E., Vale, W., 1994. Distribution of corticotropin-releasing factor receptor mRNA expression in the rat brain and pituitary. Proc. Natl. Acad. Sci. U. S. A 91, 8777-8781.

Seiler, N., Raul, F., 2005. Polyamines and apoptosis. J. Cell Mol. Med. 9, 623-642.

Smith, S.M., Vale, W.W., 2006. The role of the hypothalamic-pituitary-adrenal axis in neuroendocrine responses to stress. Dialogues. Clin. Neurosci. 8, 383-395.

Stalla, G.K., Stalla, J., von, W.K., Muller, O.A., Gerzer, R., Hollt, V., Jakobs, K.H., 1989.

Nitroimidazole derivatives inhibit anterior pituitary cell function apparently by a direct effect on the catalytic subunit of the adenylate cyclase holoenzyme. Endocrinology 125, 699-706.

Steinberger, D., Blau, N., Goriuonov, D., Bitsch, J., Zuker, M., Hummel, S., Muller, U., 2004. Heterozygous mutation in 5'-untranslated region of sepiapterin reductase gene (SPR) in a patient with dopa-responsive dystonia. Neurogenetics. 5, 187-190. 
Summers, C.H., Kampshoff, J.L., Ronan, P.J., Lowry, C.A., Prestbo, A.A., Korzan, W.J., Renner, K.J., 2003. Monoaminergic activity in subregions of raphe nuclei elicited by prior stress and the neuropeptide corticotropin-releasing factor. J. Neuroendocrinol. 15, 1122-1133.

Takano, K., Ogura, M., Nakamura, Y., Yoneda, Y., 2005. Neuronal and glial responses to polyamines in the ischemic brain. Curr. Neurovasc. Res. 2, 213-223.

Towbin, H., Ozbey, O., Zingel, O., 2001. An immunoblotting method for high-resolution isoelectric focusing of protein isoforms on immobilized $\mathrm{pH}$ gradients. Electrophoresis 22, 1887 1893.

van Amsterdam, J.G., Opperhuizen, A., 1999. Nitric oxide and biopterin in depression and stress. Psychiatry Res. 85, 33-38.

Van Pett, K., Viau, V., Bittencourt, J.C., Chan, R.K., Li, H.Y., Arias, C., Prins, G.S., Perrin, M., Vale, W., Sawchenko, P.E., 2000. Distribution of mRNAs encoding CRF receptors in brain and pituitary of rat and mouse. J. Comp Neurol. 428, 191-212.

Villen, J., Beausoleil, S.A., Gerber, S.A., Gygi, S.P., 2007. Large-scale phosphorylation analysis of mouse liver. Proc. Natl. Acad. Sci. U. S. A 104, 1488-1493.

Voges, D., Zwickl, P., Baumeister, W., 1999. The 26S proteasome: a molecular machine designed for controlled proteolysis. Annu. Rev. Biochem. 68, 1015-1068.

Wu, W., Kamma, H., Fujiwara, M., Yano, Y., Satoh, H., Hara, H., Yashiro, T., Ueno, E., Aiyoshi, Y., 2005. Altered expression patterns of heterogeneous nuclear ribonucleoproteins A2 and B1 in the adrenal cortex. J. Histochem. Cytochem. 53, 487-495. 
Yates, J.R., Eng, J.K., McCormack, A.L., Schieltz, D., 1995. Method to correlate tandem mass spectra of modified peptides to amino acid sequences in the protein database. Anal. Chem. 67, 1426-1436. 


\section{Figure Legends}

\section{Figure 1:}

ACTH levels in cell culture supernatants of control and CRH treated AtT-20 cells plotted as mean $\pm \mathrm{SEM}$. The ACTH response to the $\mathrm{CRH}$ stimulus was significantly detectable after $30 \mathrm{~min}$ of hormone incubation within the early response experiment. The late $\mathrm{CRH}$ response experiment shows that constitutive ACTH release after $6 \mathrm{~h}$ was prominent but clearly distinguishable from the CRH induced ACTH secretion.

\section{Figure 2:}

Differential change in the pattern of PSMA3 in ProQ-stained gels induced by 10 min CRH stimulation. (A) Overview of a representative 2D gel with the highlighted area indicating the position of detailed images (B) and (C). The intensity of the lower pI protein (1) decreased significantly after $10 \mathrm{~min}$ of $\mathrm{CRH}$ incubation (C) compared to the control (B), whereas the intensity of the protein with the higher pI (2) was inversely regulated. PSMA3 isoforms are indicated by arrows (1) and (2).

\section{Figure 3:}

Protein expression level of PSMA3 in AtT-20 cells that were cultured for $10 \mathrm{~min}$ in the absence and presence of $\mathrm{CRH}$, respectively. Protein extracts were analyzed by immunoblotting for PSMA3 isoforms and total PSMA3 protein amount. (A) Representative isoelectric focusing with subsequent immunoblotting of PSMA3. Several PSMA3 isoforms that separated due to differences in the $\mathrm{pI}$ were detected in the lower $\mathrm{pI}$ range. Band 1 and 2 presumably correspond to the spots that were detected as regulated within the 2D analysis of the early CRH response. 
Bands A, B and C represent additional PSMA3 isoforms. (B) Signal ratio of PSMA3 bands plotted as mean \pm SEM. A significant change was observed for the two protein isoforms 1 and 2 $(P<0.05)$ as expected from the 2D gel analysis. Additionally, we found a change with regard to isoform C. (C) Representative Western blot of PSMA3 and $\beta$-ACTIN. (D) Quantification of total PSMA3 demonstrates that there was no change in total PSMA3 protein amount following 10 min CRH treatment.

\section{Figure 4:}

Differential change in the pattern of PGAM1 and PRKAR1A in CBB-stained gels induced by $6 \mathrm{~h}$ CRH stimulation. (A) Overview of a representative 2D gel with the highlighted areas indicating the position of detailed images (B, C and D, E). (B, C) Alteration of PGAM1 following $6 \mathrm{~h}$ of CRH treatment. Under control conditions (B) only the protein spot with the higher pI (2) was present. When treated $6 \mathrm{~h}$ with $\mathrm{CRH}(\mathrm{C})$ an additional spot with a lower pI (1) appeared. This spot was already detectable after $2 \mathrm{~h}$ CRH treatment (not shown). (D, E) Two isoforms of PRKAR1A were detected in AtT-20 cells as indicated by arrows (3) and (4). The intensities of both spots increased following $6 \mathrm{~h}$ of $\mathrm{CRH}$ treatment (E) compared to control conditions (D).

\section{Figure 5:}

Protein expression levels of PGAM1 and PRKAR1A. AtT-20 cells were cultured for $6 \mathrm{~h}$ in the presence and absence of $\mathrm{CRH}$, respectively. (A) Representative Western blots of PRKAR1A, PGAM1, and $\beta$-ACTIN. Quantification of Western blot analysis of (B) PGAM1 and (C) PRKAR1A identified a significant increase of both PGAM1 $(P<0.01)$ and PRKAR1A $(P<$ 0.05) following $6 \mathrm{~h} \mathrm{CRH} \mathrm{treatment.} \mathrm{Expression} \mathrm{level} \mathrm{plotted} \mathrm{as} \mathrm{mean} \pm \mathrm{SEM}$. 


\section{Figure 6:}

Expressional analysis of candidates identified in the late $\mathrm{CRH}$ response experiment. mRNA quantification was carried out by qRT-PCR of RNA isolated from AtT-20 cells cultured for $6 \mathrm{~h}$ in the presence and absence of $\mathrm{CRH}$, respectively. Target genes with a mean change of at least $25 \%$ compared to the control and a $P<0.05$ were considered as regulated. Pomc was included in the analysis as a control to demonstrate the impact of CRH treatment $(P<0.05)$. mRNA expression levels were plotted as mean \pm SEM. 


\section{Table Legends}

\section{Table 1: Primers used for $q R T-P C R$}

Forward and reverse primers of target genes listed with the appropriate 5'-3' sequence.

\section{Table 2: Mass spectrometry analysis}

The experimental origin, the mass spectrometry method, the number of identified peptides, and the sequence coverage are specified for each identified protein. When proteins are found in two spots within one experiment, the details for the lower pI protein are listed first.

Table 3 and 4: Description of proteins that showed expression differences or posttranslational modification in AtT-20 cells upon CRH stimulation

Table 3: early CRH response. Table 4: late $\mathrm{CRH}$ response. The biological process the target protein is involved in is specified. 2D gel staining as well as statistical parameters of the CRHdependent regulation are indicated. When proteins are found in two spots within one experiment, the details for the lower pI protein are listed first. 
Table 1: Primers used for qRT-PCR

\begin{tabular}{|c|c|c|}
\hline Target Gene & Primer & Sequence 5'-3' \\
\hline Acidic ribosomal protein $\mathrm{P} 0$ & $\begin{array}{c}\text { forward } \\
\text { reverse }\end{array}$ & $\begin{array}{l}\text { catcaccacgaaaatctccag } \\
\text { cacagacaatgccaggac }\end{array}$ \\
\hline cAMP-dependent protein kinase type I- $\alpha$ regulatory & $\begin{array}{l}\text { forward } \\
\text { reverse }\end{array}$ & $\begin{array}{l}\text { gagaaggaggaggcaagac } \\
\text { agcaataaaggagactggaaac }\end{array}$ \\
\hline Eukaryotic translation elongation factor $1 \delta$ isoform $b$ & $\begin{array}{l}\text { forward } \\
\text { reverse }\end{array}$ & $\begin{array}{l}\text { gaggacgatgaggacaagga } \\
\text { tggaacgcacacaagtctct }\end{array}$ \\
\hline Expressed in non-metastatic cells 1 & $\begin{array}{l}\text { forward } \\
\text { reverse }\end{array}$ & $\begin{array}{l}\text { ccttcattgccatcaagcc } \\
\text { attcagacctcccagacc }\end{array}$ \\
\hline FK506 binding protein 1a & $\begin{array}{c}\text { forward } \\
\text { reverse }\end{array}$ & $\begin{array}{c}\text { gactgaatggctggatgg } \\
\text { gaaggaatggtttgatgggta }\end{array}$ \\
\hline Glutamate oxaloacetate transaminase-1 & $\begin{array}{c}\text { forward } \\
\text { reverse }\end{array}$ & $\begin{array}{l}\text { ttctccatctttgtcctcca } \\
\text { tagcccacgcatctttctct }\end{array}$ \\
\hline Heterogeneous nuclear ribonucleoprotein A2/B1 & $\begin{array}{c}\text { forward } \\
\text { reverse }\end{array}$ & $\begin{array}{l}\text { accaggagcccatgtgactgtg } \\
\text { caaaattgccaccgccaccac }\end{array}$ \\
\hline Hydroxymethyl-glutaryl-CoA synthase, cytoplasmic & $\begin{array}{l}\text { forward } \\
\text { reverse }\end{array}$ & $\begin{array}{c}\text { aatgccgtgaactgggtcg } \\
\text { tgaggtagcactgtatggagagc }\end{array}$ \\
\hline Hypoxanthine guanine phosphoribosyl transferase & $\begin{array}{l}\text { forward } \\
\text { reverse }\end{array}$ & $\begin{array}{l}\text { acctctcgaagtgttggatacagg } \\
\text { cttgcgctcatcttaggetttg }\end{array}$ \\
\hline Niemann-Pick type C2 & $\begin{array}{l}\text { forward } \\
\text { reverse }\end{array}$ & $\begin{array}{l}\text { cctattcctgagcetgacggttg } \\
\text { gcctagcttgtgatctgaactggg }\end{array}$ \\
\hline Nudix-type motif 5 & $\begin{array}{l}\text { forward } \\
\text { reverse }\end{array}$ & $\begin{array}{l}\text { tcctcaatccettccacatc } \\
\text { attctcgggtctccatttcg }\end{array}$ \\
\hline Phosphoglycerate kinase 1 & $\begin{array}{l}\text { forward } \\
\text { reverse }\end{array}$ & $\begin{array}{l}\text { gaagggaagggaaaagatgc } \\
\text { gctatgggctcggtgtgc }\end{array}$ \\
\hline Phosphoglycerate mutase 1 & $\begin{array}{l}\text { forward } \\
\text { reverse }\end{array}$ & $\begin{array}{l}\text { acccettctacagcaacatc } \\
\text { cgcettcacttcttcacc }\end{array}$ \\
\hline Proopiomelanocortin & $\begin{array}{c}\text { forward } \\
\text { reverse }\end{array}$ & $\begin{array}{l}\text { atagatgtgtggagctggtgc } \\
\text { ggctctggactgccatctc }\end{array}$ \\
\hline Proteasome (prosome, macropain) 26S subunit, & $\begin{array}{l}\text { forward } \\
\text { reverse }\end{array}$ & $\begin{array}{l}\text { gcggaccagcggaaaaccaaag } \\
\text { gtgccaacccagtgtcagactc }\end{array}$ \\
\hline Proteasome (prosome, macropain) subunit, $\alpha$ type 3 & $\begin{array}{c}\text { forward } \\
\text { reverse }\end{array}$ & $\begin{array}{l}\text { ttgtcagectctacgttctctcetg } \\
\text { aacctgcaactgecattccaac }\end{array}$ \\
\hline RNA exonuclease 2 homolog & $\begin{array}{l}\text { forward } \\
\text { reverse }\end{array}$ & $\begin{array}{l}\text { cctgcctgataactgactctg } \\
\text { agtgtgactgtgctctcc }\end{array}$ \\
\hline Sepiapterin reductase & $\begin{array}{c}\text { forward } \\
\text { reverse }\end{array}$ & $\begin{array}{l}\text { gectgagcaagactgtggtt } \\
\text { aggtttcccgagccaact }\end{array}$ \\
\hline Spermidine synthase & $\begin{array}{c}\text { forward } \\
\text { reverse }\end{array}$ & $\begin{array}{l}\text { aacctacggcaacgtgctgg } \\
\text { aatctcgcactggaccaccg }\end{array}$ \\
\hline Stress-induced phosphoprotein & $\begin{array}{l}\text { forward } \\
\text { reverse }\end{array}$ & $\begin{array}{l}\text { tgacctgaagcctgactgg } \\
\text { atttcctctctgccaacctg }\end{array}$ \\
\hline
\end{tabular}


Table 2: Mass spectrometry analysis

\begin{tabular}{|c|c|c|c|c|c|}
\hline Protein name & $\begin{array}{l}\text { Swiss-Prot } \\
\text { entry }\end{array}$ & $\begin{array}{c}\text { CRH } \\
\text { response } \\
\text { experiment }\end{array}$ & $\begin{array}{l}\text { Mass } \\
\text { spectrometry } \\
\text { method }\end{array}$ & $\begin{array}{c}\text { No. of } \\
\text { peptides }\end{array}$ & $\begin{array}{c}\text { Sequence } \\
\text { coverage } \\
(\%)\end{array}$ \\
\hline \multirow{2}{*}{ Acidic ribosomal protein $\mathrm{P} 0$} & \multirow{2}{*}{ P14869 } & \multirow{2}{*}{ late } & nano-ESI & 5 & 16 \\
\hline & & & MALDI & 11 & 44 \\
\hline \multirow{2}{*}{$\begin{array}{l}\text { cAMP-dependent protein kinase } \\
\text { type I- } \alpha \text { regulatory subunit }\end{array}$} & \multirow{2}{*}{ Q9DBC7 } & \multirow{2}{*}{ late } & nano-ESI & 6 & 17 \\
\hline & & & nano-ESI & 6 & 17 \\
\hline $\begin{array}{l}\text { Eukaryotic translation } \\
\text { elongation factor } 1 \delta\end{array}$ & Q68FG5 & early & nano-ESI & 5 & 22 \\
\hline $\begin{array}{l}\text { Expressed in non-metastatic } \\
\text { cells } 1 \text { protein }\end{array}$ & Q5NC80 & late & MALDI & 9 & 56 \\
\hline FK506 binding protein 1a & P26883 & late & MALDI & 7 & 41 \\
\hline $\begin{array}{l}\text { Glutamate oxaloacetate } \\
\text { transaminase- } 1\end{array}$ & P05201 & late & nano-ESI & 18 & 44 \\
\hline $\begin{array}{l}\text { Heterogeneous nuclear } \\
\text { ribonucleoprotein A2/B1 }\end{array}$ & O88569 & late & nano-ESI & 7 & 24 \\
\hline $\begin{array}{l}\text { Hydroxymethyl-glutaryl-CoA } \\
\text { synthase, cytoplasmic }\end{array}$ & Q8JZK9 & late & nano-ESI & 4 & 8 \\
\hline Niemann-Pick type C2 & Q9Z0J0 & early & nano-ESI & 2 & 14 \\
\hline Nudix-type motif 5 & Q9JKX6 & early & nano-ESI & 6 & 29 \\
\hline Phosphoglycerate kinase 1 & P09411 & late & nano-ESI & 8 & 20 \\
\hline Phosphoglycerate mutase 1 & Q9DBJ1 & late & nano-ESI & 4 & 17 \\
\hline $\begin{array}{c}\text { Proteasome } 26 \mathrm{~S} \text { subunit, } \\
\text { ATPase } 2\end{array}$ & P46471 & early & nano-ESI & 10 & 24 \\
\hline \multirow{2}{*}{ Proteasome subunit, $\alpha$ type 3} & \multirow{2}{*}{ O70435 } & \multirow{2}{*}{ early } & MALDI & 9 & 30 \\
\hline & & & MALDI & 2 & 14 \\
\hline Proteasome subunit, $\alpha$ type 3 & O70435 & late & nano-ESI & 7 & 29 \\
\hline RNA exonuclease 2 homolog & Q9D8S4 & late & nano-ESI & 9 & 30 \\
\hline Sepiapterin reductase & Q64105 & early & MALDI & 7 & 35 \\
\hline \multirow{2}{*}{ Spermidine synthase } & \multirow{2}{*}{ Q64674 } & \multirow{2}{*}{ early } & MALDI & 10 & 52 \\
\hline & & & MALDI & 8 & 39 \\
\hline \multirow{2}{*}{ Stress-induced phosphoprotein } & \multirow{2}{*}{ Q60864 } & \multirow{2}{*}{ early } & nano-ESI & 2 & 5 \\
\hline & & & nano-ESI & 7 & 14 \\
\hline
\end{tabular}


Table 3: Description of proteins that show differences in expression or posttranslational modification in AtT-20 cells -

\section{early CRH response}

\begin{tabular}{|c|c|c|c|c|c|c|c|c|c|c|c|}
\hline \multirow{3}{*}{ Protein name } & \multirow{3}{*}{ Symbol } & \multirow{3}{*}{$\begin{array}{l}\text { Swiss-Prot } \\
\text { entry }\end{array}$} & \multirow{3}{*}{ Biological process } & \multirow{3}{*}{ Stain } & \multirow{3}{*}{$\begin{array}{c}\text { one-way } \\
\text { ANOVA } \\
P \text { value }\end{array}$} & \multicolumn{6}{|c|}{ Newman-Keuls Comparison Test } \\
\hline & & & & & & \multicolumn{2}{|c|}{ control vs $5 \mathrm{~min}$} & \multicolumn{2}{|c|}{ control vs $10 \mathrm{~min}$} & \multicolumn{2}{|c|}{ control vs $30 \mathrm{~min}$} \\
\hline & & & & & & $P$ value & Fold & $P$ value & fold & $P$ value & fold \\
\hline $\begin{array}{l}\text { Eukaryotic translation elongation } \\
\text { factor } 1 \delta\end{array}$ & EEF1D & Q68FG5 & Translation & $\mathrm{CBB}$ & $<0,01$ & $<0,01$ & $-8,4$ & $<0,01$ & $-9,1$ & $<0,01$ & $-5,4$ \\
\hline Niemann-Pick type $\mathrm{C} 2$ & $\mathrm{NPC} 2$ & Q9Z0J0 & Cholesterol homeostasis & ProQ & $<0,01$ & $<0,05$ & $-7,8$ & $<0,01$ & $-5,0$ & $<0,01$ & $-7,7$ \\
\hline Nudix-type motif 5 & NUDT5 & Q9JKX6 & Nucleic acid metabolism & ProQ & $<0,05$ & n.s. & 1,0 & $<0,05$ & $-2,0$ & $<0,05$ & $-2,1$ \\
\hline Proteasome $26 \mathrm{~S}$ subunit, ATPase 2 & PSMC2 & P46471 & Proteolysis & ProQ & $<0,05$ & n.s. & 1,5 & n.s. & 1,4 & $<0,05$ & 1,9 \\
\hline \multirow{2}{*}{ Proteasome subunit, $\alpha$ type 3} & \multirow{2}{*}{ PSMA3 } & \multirow{2}{*}{ O70435 } & \multirow{2}{*}{ Proteolysis } & \multirow{2}{*}{ ProQ } & $<0,01$ & $<0,05$ & $-2,4$ & $<0,01$ & $-4,0$ & $<0,05$ & $-1,8$ \\
\hline & & & & & n.s. & n.s. & 4,2 & n.s. & 7,9 & n.s. & 3,1 \\
\hline Sepiapterin reductase & SPR & Q64105 & $\begin{array}{l}\text { Tetrahydrobiopterin } \\
\text { biosynthesis }\end{array}$ & $\mathrm{CBB}$ & $<0,001$ & $<0,001$ & $-10,9$ & $<0,001$ & $-7,6$ & $<0,001$ & $-5,0$ \\
\hline Spermidine synthase & SRM & Q64674 & Spermidine biosynthesis & ProQ & $<0,001$ & n.s. & $-1,2$ & $<0,05$ & $-22,3$ & $<0,05$ & $-10,3$ \\
\hline \multirow{2}{*}{ Stress-induced phosphoprotein 1} & \multirow{2}{*}{ STIP1 } & \multirow{2}{*}{ Q60864 } & \multirow{2}{*}{$\begin{array}{l}\text { Association of the molecular } \\
\text { chaperones }\end{array}$} & \multirow{2}{*}{ ProQ } & $<0,05$ & $<0,05$ & 1,2 & n.s. & 2,0 & n.s. & 1,0 \\
\hline & & & & & $<0,05$ & $<0,05$ & $-1,6$ & $<0,05$ & $-1,8$ & $<0,05$ & $-3,0$ \\
\hline
\end{tabular}


Table 4: Description of proteins that show differences in expression or posttranslational modification in AtT-20 cells -

\section{late CRH response}

\begin{tabular}{|c|c|c|c|c|c|c|c|c|c|c|c|}
\hline \multirow{3}{*}{ Protein name } & \multirow{3}{*}{ Symbol } & \multirow{3}{*}{$\begin{array}{l}\text { Swiss-Prot } \\
\text { entry }\end{array}$} & \multirow{3}{*}{ Biological process } & \multirow{3}{*}{ Stain } & \multirow{3}{*}{$\begin{array}{c}\text { One-way } \\
\text { ANOVA } \\
P \text { value }\end{array}$} & \multicolumn{6}{|c|}{ Newman-Keuls Comparison Test } \\
\hline & & & & & & Contro & $\mathrm{s} 1 \mathrm{~h}$ & Contro & $\mathrm{s} 2 \mathrm{~h}$ & Contro & s $6 \mathrm{~h}$ \\
\hline & & & & & & $P$ value & fold & $P$ value & fold & $P$ value & fold \\
\hline \multirow{2}{*}{ Acidic ribosomal protein P0 } & \multirow{2}{*}{ ARBP } & \multirow{2}{*}{ P14869 } & \multirow{2}{*}{$\begin{array}{l}\text { Structural constituent of } \\
\text { ribosome }\end{array}$} & \multirow{2}{*}{ ProQ } & $<0,0001$ & $<0,001$ & 2,3 & $<0,001$ & 2,5 & $<0,001$ & 2,0 \\
\hline & & & & & $<0,001$ & $<0,001$ & 2,5 & $<0,001$ & 2,4 & $<0,001$ & 2,5 \\
\hline \multirow{2}{*}{$\begin{array}{l}\text { cAMP-dependent protein kinase } \\
\text { type I- } \alpha \text { regulatory subunit }\end{array}$} & \multirow{2}{*}{ PRKAR1A } & \multirow{2}{*}{ Q9DBC7 } & \multirow{2}{*}{ Signal transduction } & \multirow{2}{*}{$\mathrm{CBB}$} & $<0,05$ & n.s. & 1,4 & $<0,05$ & 2,4 & $<0,05$ & 3,0 \\
\hline & & & & & n.s. & n.s. & 2,1 & n.s. & 2,3 & n.s. & 2,5 \\
\hline $\begin{array}{l}\text { Expressed in non-metastatic } \\
\text { cells } 1 \text { protein }\end{array}$ & NME1 & Q5NC80 & $\begin{array}{c}\text { Nucleoside triphosphate } \\
\text { biosynthesis; regulation of } \\
\text { proliferation }\end{array}$ & $\mathrm{CBB}$ & $<0,05$ & $<0,05$ & $-3,4$ & $<0,05$ & $-1,9$ & $<0,05$ & $-3,4$ \\
\hline FK506 binding protein 1a & FKBP1A & P26883 & Protein folding & CBB & $<0,01$ & n.s. & $-1,2$ & $<0,05$ & $-1,6$ & $<0,01$ & $-2,3$ \\
\hline $\begin{array}{l}\text { Glutamate oxaloacetate } \\
\text { transaminase-1 }\end{array}$ & GOT1 & P05201 & Aspartate catabolism & $\mathrm{CBB}$ & $<0,05$ & n.s. & 1,6 & $<0,05$ & 2,8 & $<0,05$ & 3,2 \\
\hline $\begin{array}{l}\text { Heterogeneous nuclear } \\
\text { ribonucleoprotein A2/B1 }\end{array}$ & HNRPA2B1 & O88569 & mRNA splicing & ProQ & $<0,001$ & n.s. & 1,1 & $<0,01$ & $-2,9$ & $<0,01$ & $-3,8$ \\
\hline $\begin{array}{l}\text { Hydroxymethyl-glutaryl-CoA } \\
\text { synthase, cytoplasmic }\end{array}$ & HMGCS11 & Q8JZK9 & $\begin{array}{c}\text { Acetyl coenzyme A metabolic } \\
\text { process }\end{array}$ & $\mathrm{CBB}$ & 0,001 & n.s. & $-1,1$ & $<0,01$ & 2,4 & n.s. & 1,7 \\
\hline Phosphoglycerate kinase 1 & PGK1 & P09411 & Glycolysis & CBB & $<0,05$ & n.s. & 1,1 & n.s. & -14 & $<0,05$ & $-3,0$ \\
\hline Phosphoglycerate mutase 1 & PGAM1 & Q9DBJ1 & Glycolysis & CBB & $<0,01$ & n.s. & 1,0 & $<0,05$ & 35,6 & $<0,01$ & 47,8 \\
\hline Proteasome subunit, $\alpha$ type 3 & PSMA3 & O70435 & Proteolysis & $\mathrm{CBB}$ & $<0,01$ & $<0,01$ & $-2,6$ & $<0,01$ & $-2,3$ & n.s. & 1,2 \\
\hline RNA exonuclease 2 homolog & REXO2 & Q9D8S4 & Nucleic acid metabolism & CBB & $<0,001$ & $<0,01$ & $-1,7$ & $<0,01$ & $-2,9$ & $<0,001$ & $-6,1$ \\
\hline
\end{tabular}




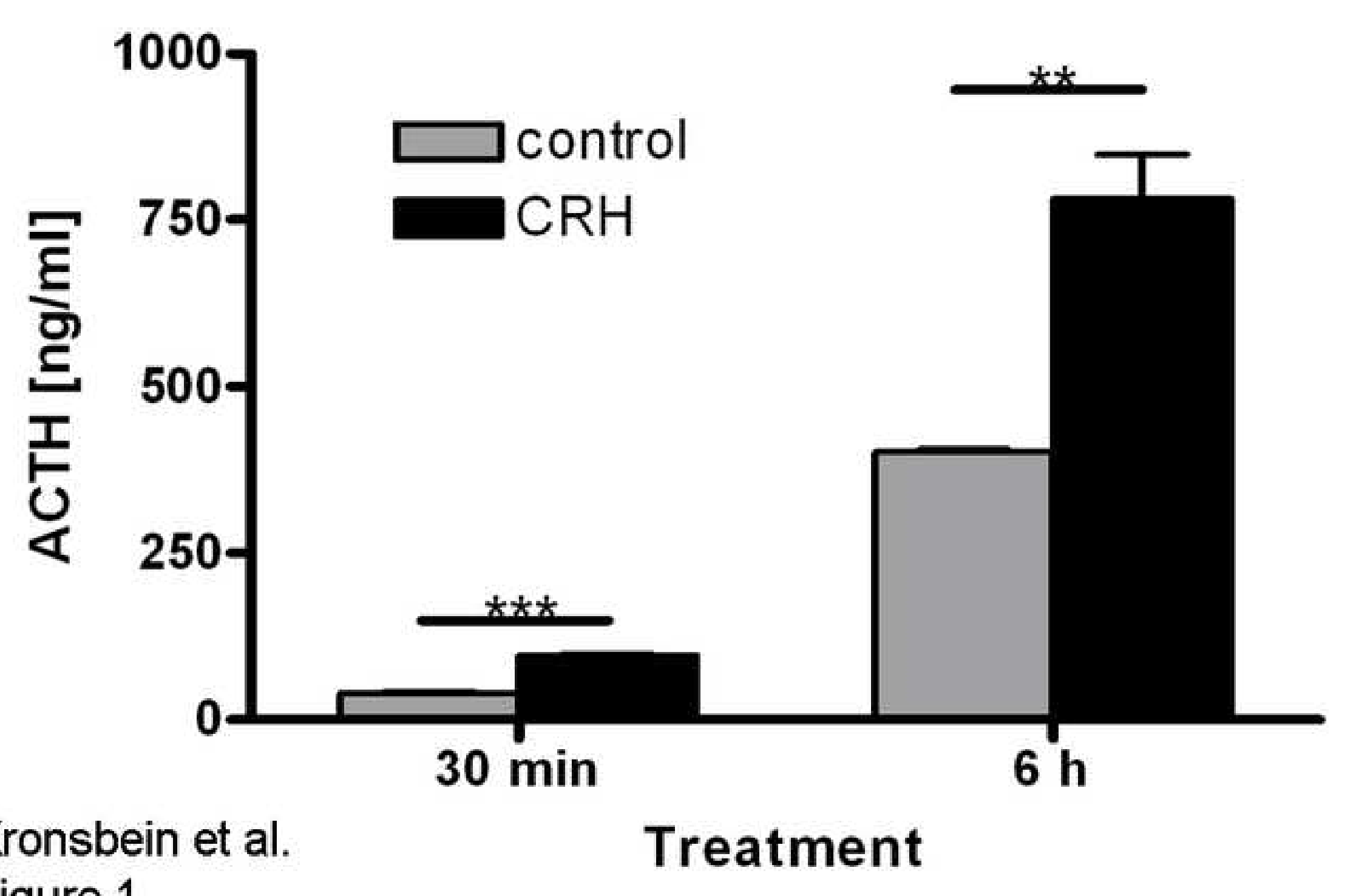

Figure 1

Kronsbein et al.

(

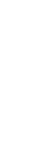


A

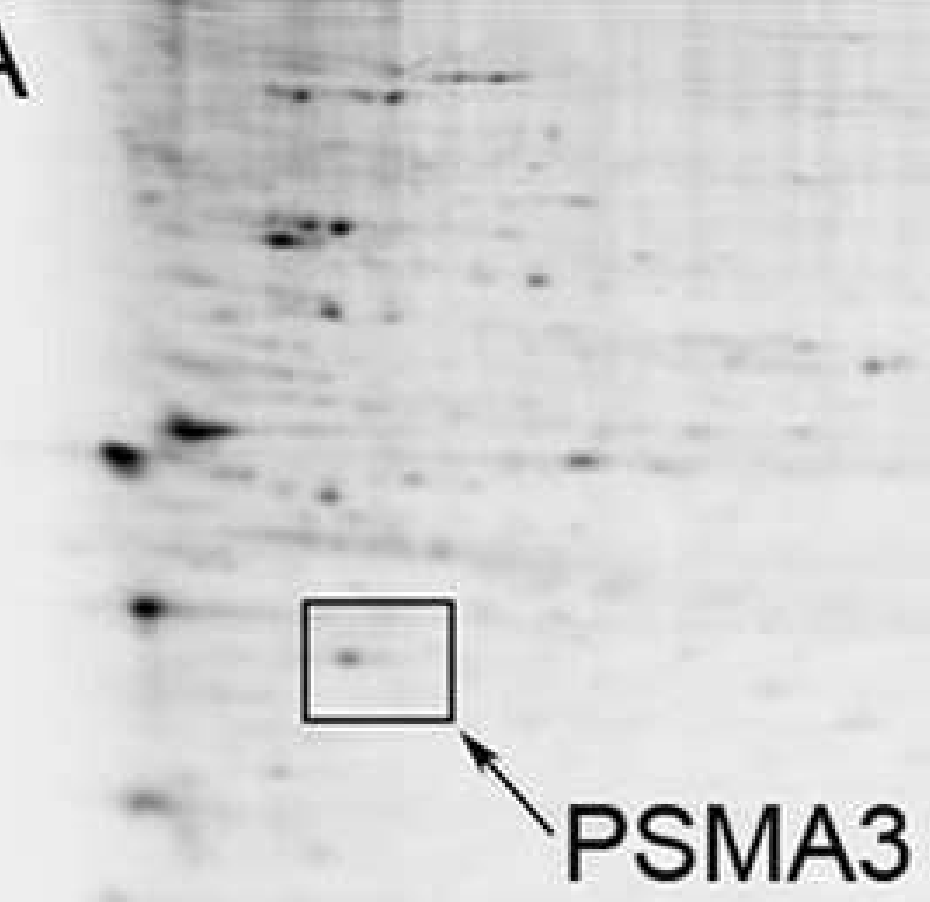

$\mathrm{pH}$ gradient

Figure 2

Kronsbein et al.

\section{.}

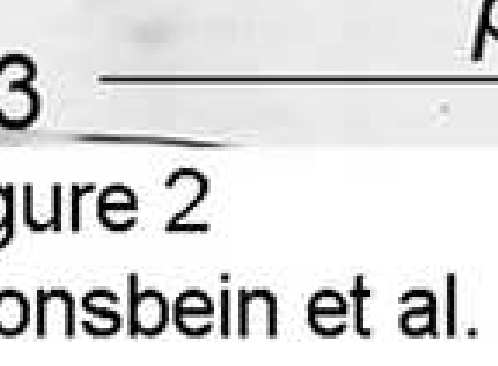

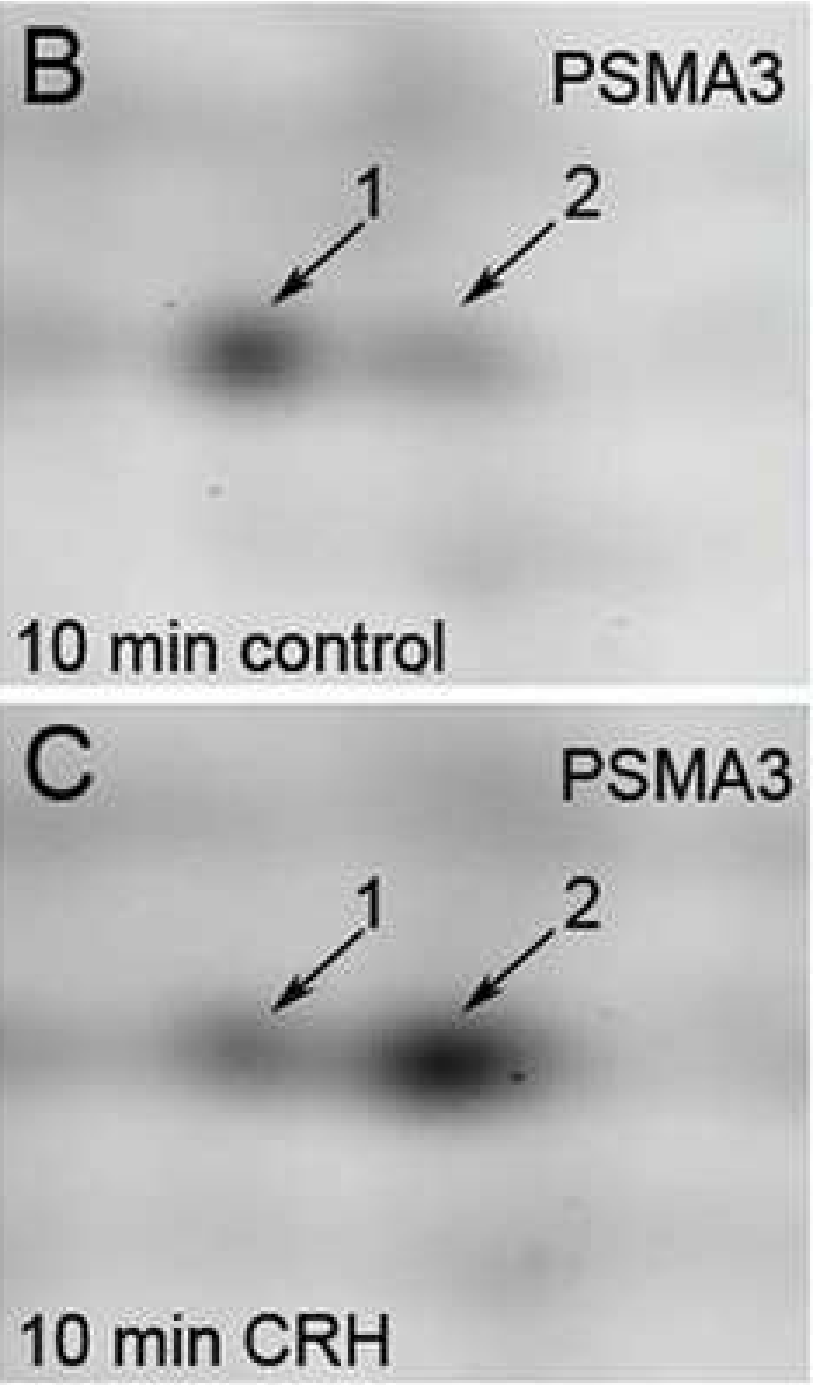

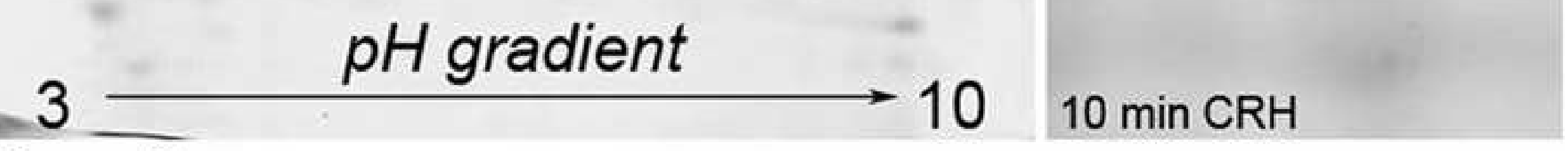


A

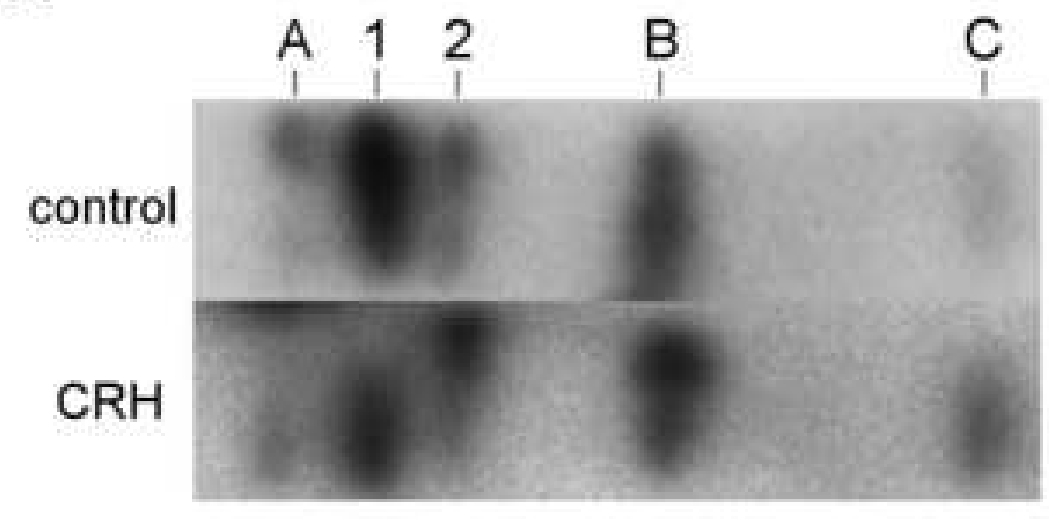

C

control CRH

$\beta$-ACTIN

PSMA3

Figure 3

Kronsbein et al.
B

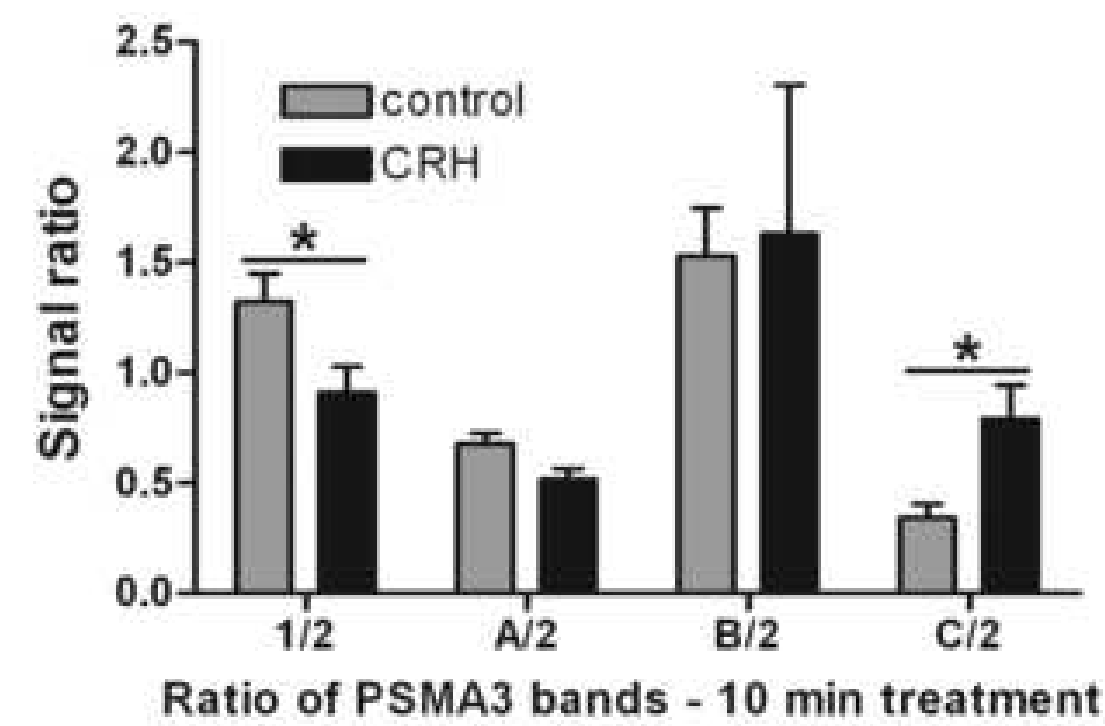

D

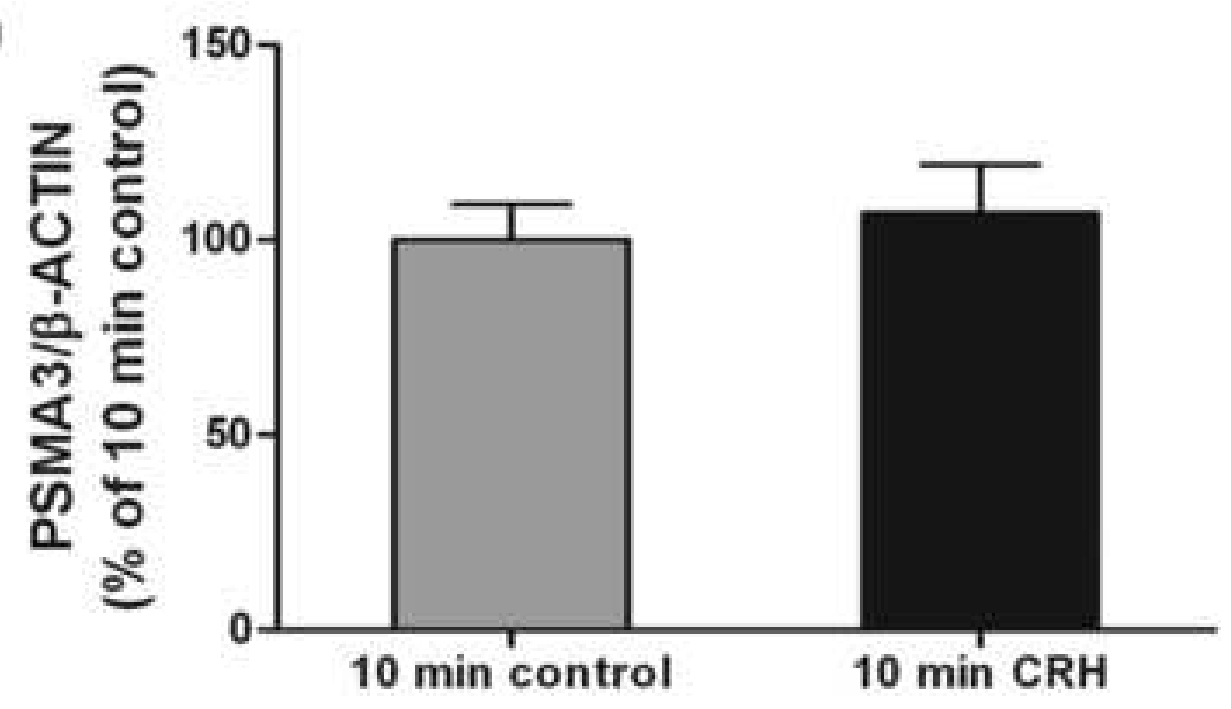



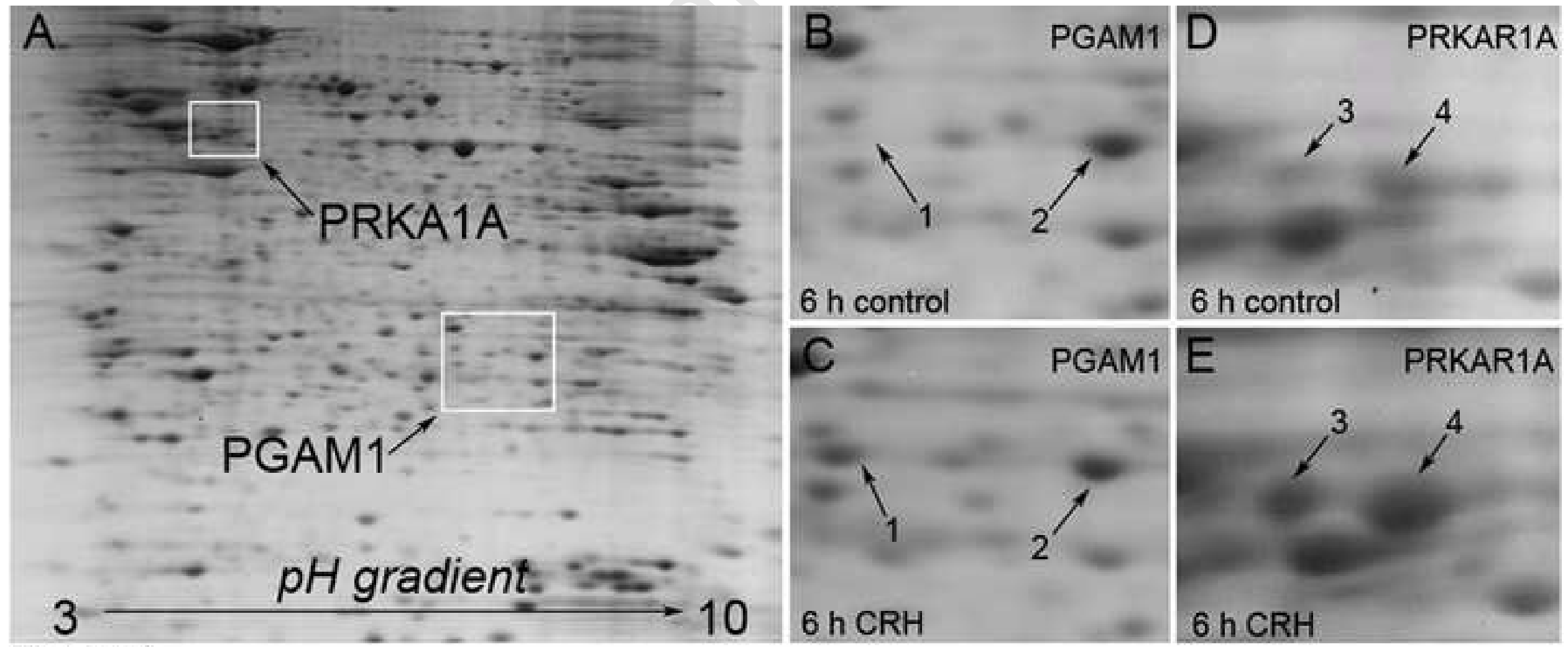

Figure 4

Kronsbein et al. 


\section{Figure 5}

A

Figure 5

Kronsbein et al,
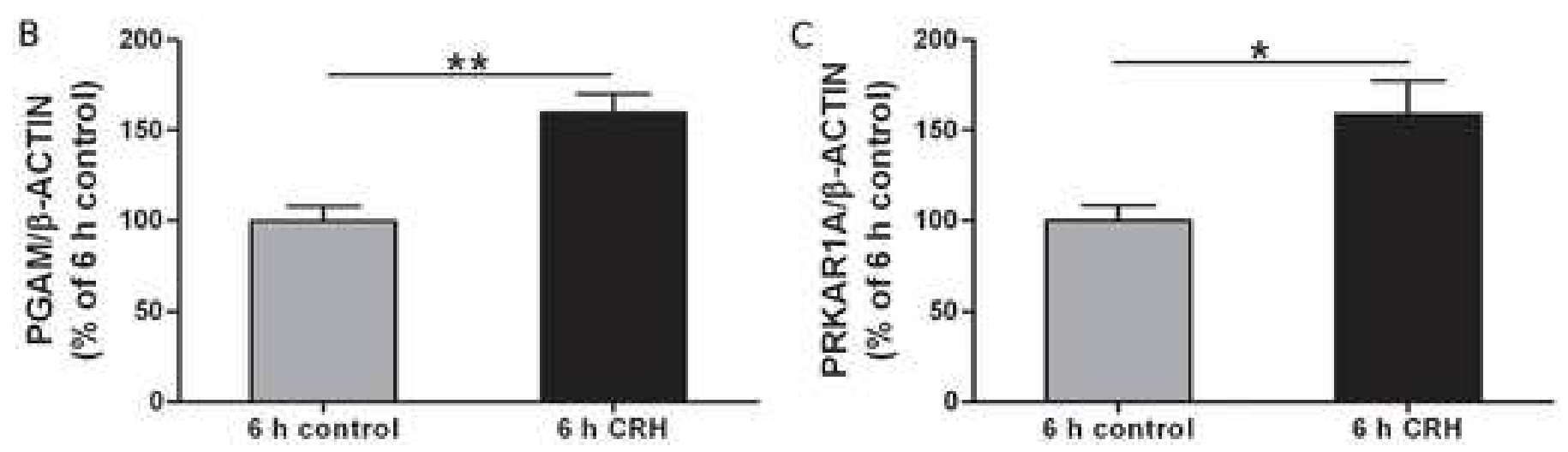


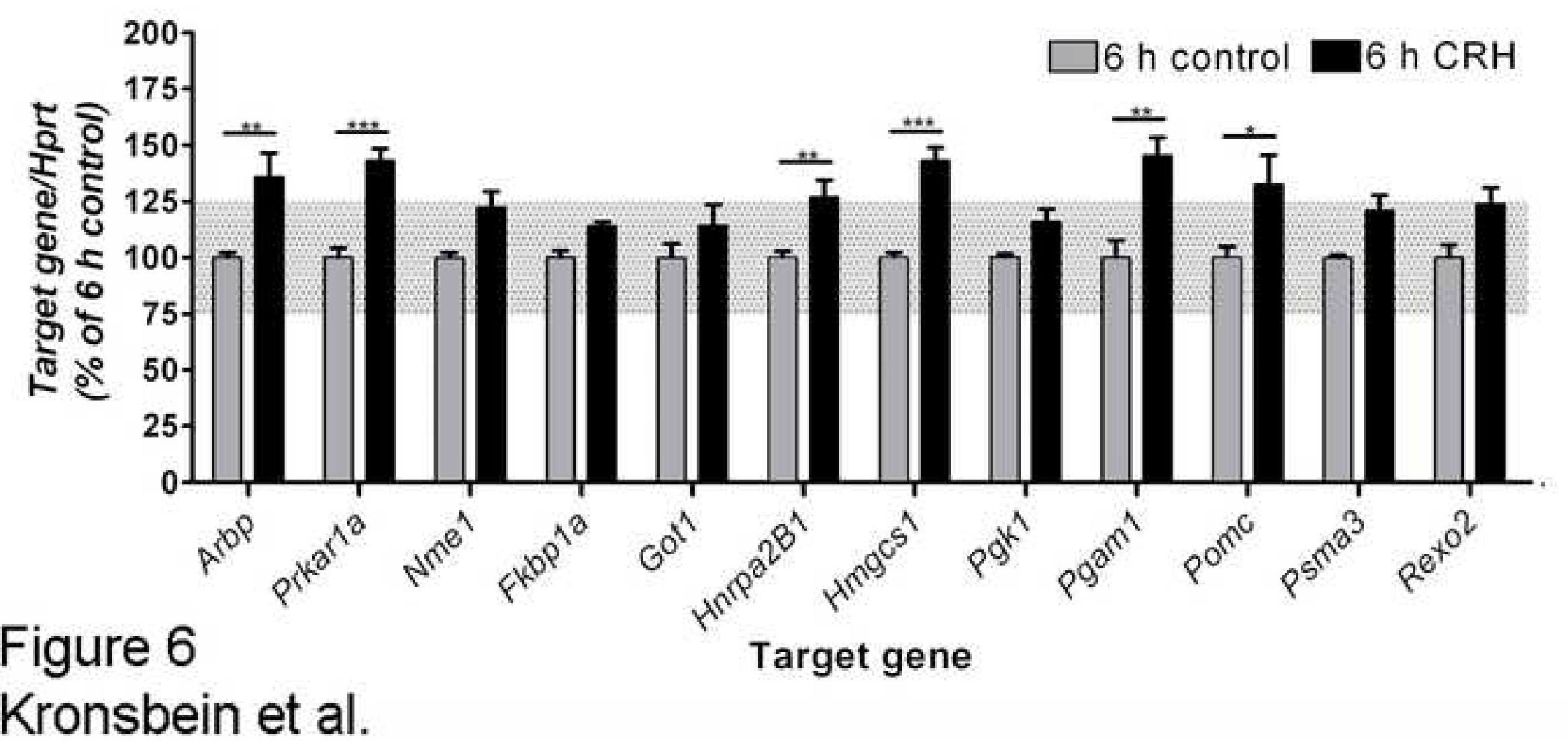

